\title{
Spatial characteristics of severe storms in Hong Kong
}

\section{Gao and L. M. Zhang}

Department of Civil and Environmental Engineering, The Hong Kong University of Science and Technology, Clear Water Bay, Hong Kong

Received: 14 May 2015 - Accepted: 22 June 2015 - Published: 24 July 2015

Correspondence to: L. M. Zhang (cezhangl@ust.hk)

Published by Copernicus Publications on behalf of the European Geosciences Union.

Spatial

characteristics of severe storms in

Hong Kong

L. Gao and L. M. Zhang

Title Page

Abstract

Introduction

Conclusions

References

Tables

Figures

14

$>1$

4

Back

Close

Full Screen / Esc

Printer-friendly Version

Interactive Discussion 


\section{Abstract}

A storm may cause serious damage to infrastructures and public safety. The storm spatial distribution is an important piece of information in drainage system design and landslide hazard analysis. The primary objective of this paper is to quantify the 5 spatial characteristics of three severe storms in Hong Kong. The maximum rolling 4, 24 and $36 \mathrm{~h}$ rainfall amounts of these storms are introduced firstly. Then the spatial structure of precipitation represented by semivariograms is analysed in both isotropic and anisotropic cases. Afterwards, the distribution of rainfall in spatial domain is assessed via surface trend fitting. Finally the spatial correlation of detrended residuals is determined through studying the scales of fluctuation along eight directions. The spatial distribution of the maximum rolling rainfall can be represented by a rotated ellipsoid trend surface and a random field of residuals. The principal directions of the surface trend are between 25 and $45^{\circ}$. The scales of fluctuation of the detrended residuals are found between 5 and $25 \mathrm{~km}$ according to the semivariograms and affected by the rainfall duration. The scale of fluctuation becomes smaller as the rainfall duration increases. Such spatial characteristics are related to the local terrain and meteorology factors.

\section{Introduction} pose risks to lives and properties. A severe storm may cause serious damage to infrastructures and public safety. For instance, a storm hit Lantau Island, Hong Kong, on 5-7 June 2008 and caused about 1600 natural terrain landslides and an economic loss of HKD 578 million (Greenpeace China, 2009). In hazards mitigation and engineering design, certain "design storms" must be considered and the engineering system should be sufficiently safety under such design storms. A design storm is often defined by
HESSD

$12,6981-7021,2015$

Spatial

characteristics of

severe storms in

Hong Kong

L. Gao and L. M. Zhang

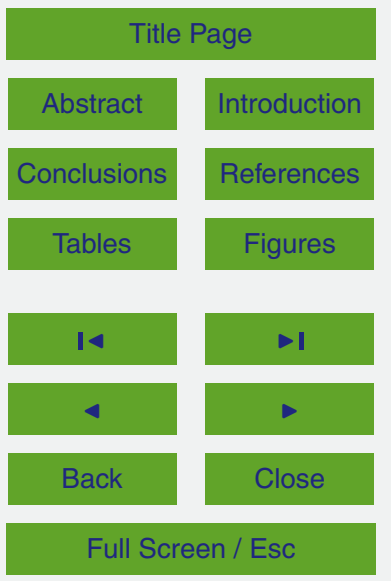

Printer-friendly Version

Interactive Discussion 
a hyetograph (time distribution) and an isohyet (spatial distribution). For a particular region where the spatial rainfall variation is significant, a uniform representation of the spatial distribution is not reasonable since a storm has a centre and influences a limited area. Instead, spatial variation factors of rainfall must be characterized, such as the 5 geometry of spatial form (agglomerate and local gradient) and the spatial dependency (continuity and variability).

A storm is difficult to model due to its intermittence (presence of zero values) and strong spatial and temporal heterogeneity (e.g., Waymire and Gupta, 1981; Barancourt et al., 1992; Bacchi and Kottegoda, 1995; Mascaro, 2013). However, the rainfall amount 10 which is in form of regionalized variables (Webster and Oliver, 2007; Panthou et al., 2014 ) is spatially correlated over a certain distance. A regionalized variable is any variable distributed in space. Geostatistics with its origin in mining is recognized as a suitable theory for describing regionalized variables (Matheron, 1965). Geostatistical techniques considering spatial correlation have been proven effective for the structural 15 analysis of regionalized variables through the use of variograms (e.g., Bras and Rodríguez-Iturbe, 1985; Goovaerts, 2000). Geostatistical models have also been used in spatial storm analysis (Rodriguez-Iturbe and Meija, 1974), and adopted to describe storm spatial structures (e.g., Lebel and Laborde, 1988; Kyriakidis and Journel, 1999; Berne et al., 2009). Research on spatial rainfall using geostatistical models has been performed in Hong Kong for different engineering purposes (Leung and Law, 2002; Jiang and Tung, 2014). Leung and Law (2002) conducted kriging analysis on the Hong Kong hourly rainfall data in 1997 and 1998. Based on the results, rainfall contours were interpolated to qualitatively estimate the possible flooding locations. Jiang and Tung (2014) derived rainfall depth-duration-frequency relations at ungauged sites in Hong Kong using an ordinary kriging approach based on annual maximum daily rainfall data. The extreme rainfall estimates are sensitive to assumed statistical parameters and uncertainties of the interpolation method.

In previous studies, the storm characteristics such as distribution form and spatial correlation are not sufficiently analysed when studying the hydrological response of
HESSD

12, 6981-7021, 2015

Spatial

characteristics of

severe storms in

Hong Kong

L. Gao and L. M. Zhang

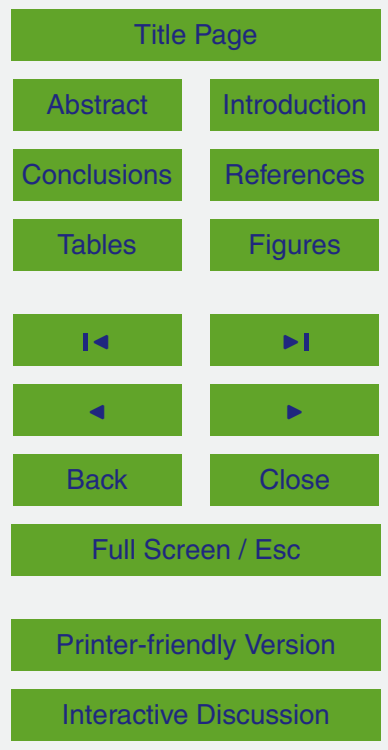


a target system such as a slope safety system for a city. In particular, limited attention has been paid to severe storms in Hong Kong, whose patterns and structures may be quite different from those of ordinary heavy rainfall. Such a research gap motivates the present study on the spatial characteristics of severe storms over hilly terrains in Hong 5 Kong.

This paper aims to quantify the characteristic parameters of spatial properties of three severe storms in Hong Kong using geostatistical methods. The paper includes three parts. First, the historic records of three selected severe storms in Hong Kong are presented. Then the methods for assessing the rainfall distribution trend surface and 10 describing the rainfall spatial correlations are described. Finally, the spatial properties of the precipitation amounts of the three severe storms are analysed. The outcome will provide information for simulating severe storms for slope safety assessment and flood risk evaluation.

\section{Precipitation data of three severe storms in Hong Kong}

15 Hong Kong is located on the southeast coast of China. Its subtropical climate is characterized by distinguished dry and wet seasons. About $85 \%$ of the annual rainfall is recorded during the wet season from April to September. Storms with high intensity and short duration in Hong Kong are typically associated with southwest monsoon or tropical cyclones. The most traditional way to describe the storm severity is by return period, which is recognized as a combination of intensity and duration. Another measure of the severity of a storm is the consequence of the storm, such as raininduced landslides or flooding. An index measuring the potential to trigger landslides, named "Landslide Potential Index (LPI)", is used in Hong Kong (CEDD, 2009). The LPI is based on the historic records of landslide events since 1984. For instance, a storm

in late July 1994 caused 5 fatalities and its LPI was 10. The value of LPI can be greater than 10 if a storm is more damaging than the July 1994 storm. According to the LPI, the top three most severe storms in the past 20 years were the 5-7 June 2008 storm,
HESSD

$12,6981-7021,2015$

Spatial

characteristics of

severe storms in

Hong Kong

L. Gao and L. M. Zhang

Title Page

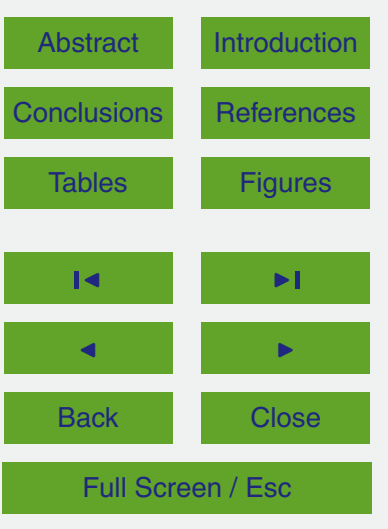

Printer-friendly Version

Interactive Discussion 
the 17-21 August 2005 storm and the 23 July 1994 storm. Each of these three storms had an LPI around 10 and led to fatalities. Thus, the three storm events are selected as indicative severe storms to conduct spatial correlation analysis in this paper.

The rainfall data in this study is provided by Geotechnical Engineering Office (GEO) 5 in Hong Kong. The GEO rain gauge network comprises 88 stations (Fig. 1). The rain gauges are more concentrated in the northern part of Hong Kong Island and Kowloon where the population density is high. The raw digital data at 5 min intervals from the high-quality network ensures the reliability of this study. The data covers the period from 00:00 LT on 5 June to 24:00 LT on 7 June 2008, from 00:00 LT on 17 August to 10 08:00 LT on 22 August 2005, and from 08:00 LT on 21 July to 24:00 LT on 24 July 1994. Some of the rain gauges had not been installed in July 1994 . The numbers of available rain gauges for the three events are 81,85 , and 43 , respectively. The three storm hyetographs corresponding to the maximum local precipitation depth are shown in Fig. 2. The 17-21 August 2005 storm is more moderate in short durations compared 15 with the 5-7 August 2008 storm and the 22-24 July 1994 storm.

\subsection{The 5-7 June 2008 storm}

According to Hong Kong Observatory (HKO), the weather was influenced by an active low pressure trough over the south China coastal area during the first 10 days of June 2008 , and was heavily rainy and thundery. Figures $3 a$ and b show scatters and 20 contours of the total rainfall amount of the 5-7 June 2008 storm. The maximum total rainfall amount was $670 \mathrm{~mm}$. The storm centre was on the southeast of Lantau Island. The magnitude of the storm is assessed corresponding to a depth-area relation, and characterized by the probable maximum precipitation (PMP). PMP is frequently used to quantify extreme storm events (WMO, 2009). The scenarios of 4 and $24 \mathrm{~h}$ PMP 25 for Hong Kong have been assessed by HKO (Chang and Hui, 2001; AECOM, 2014). The magnitudes of the storm characterized by 4 and $24 \mathrm{~h}$ PMP are shown in Fig. 4. From the depth-area relationships, when the area is in the range of $50-1100 \mathrm{~km}^{2}$, the maximum rolling $4 \mathrm{~h}$ rainfall of the 5-7 June 2008 storm has a return period of 6985
HESSD

12, 6981-7021, 2015

Spatial

characteristics of

severe storms in

Hong Kong

L. Gao and L. M. Zhang

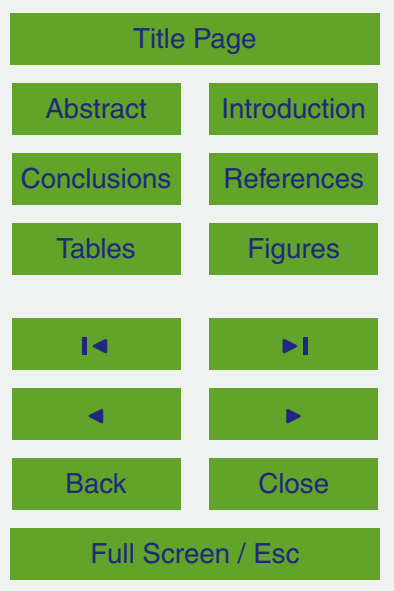

Printer-friendly Version

Interactive Discussion 
1100 years corresponding to $60-67 \%$ of the $4 \mathrm{~h}$ PMP, while the return period for the $24 \mathrm{~h}$ rainfall is 200 years, corresponding to $33-41 \%$ of the $24 \mathrm{~h}$ PMP. The storm caused 863 genuine landslides ( $\mathrm{Li}$ et al., 2009), including many debris flows that affected developed regions, leading to 2 fatalities (CEDD, 2008). The LPI value was recognized 5 as 12.

\subsection{The 17-22 August 2005 storm}

The August 2005 was much wetter than usual. A very active southwest monsoon during 17-22 August brought in plenty of moisture. Figure 3d shows contours of the total amount of rainfall. The maximum total rainfall amount was $890 \mathrm{~mm}$. The storm centre was at the middle of the territory, Shatin. From Fig. 4, both the maximum rolling $4 \mathrm{~h}$ rainfall and $24 \mathrm{~h}$ rainfall of the 17-22 August 2005 storm are least critical among the three storms investigated in this paper. The storm caused 229 reported landslides, resulting in one fatality. The LPI value was 10 (Kong and $\mathrm{Ng}, 2006$ ).

\subsection{The 21-24 July 1994 storm}

15 The total precipitation amount in the storm event from 21 to 24 July 1994 was recorded as the highest for any consecutive days in July. The weather was related to a northward shift of the intertropical convergence zone over the South China Sea coupled with the presence of a region of divergence at $200 \mathrm{hPa}$ (Tam et al., 1995). Figure 3 shows contours of the total amount of rainfall of this storm cantering at the middle of New the maximum rolling $24 \mathrm{~h}$ rainfall is the most critical, especially for a smaller area. The storm caused 436 genuine landslides, resulting in 5 fatalities and 4 injuries. The LPI value was 10 (Chan, 1995).

HESSD

12, 6981-7021, 2015

Spatial

characteristics of

severe storms in

Hong Kong

L. Gao and L. M. Zhang

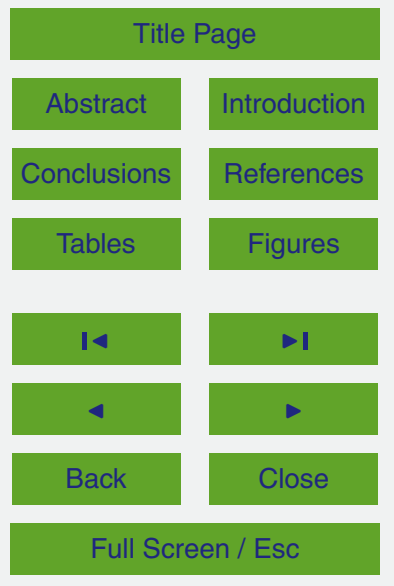

Printer-friendly Version

Interactive Discussion 


\subsection{Summary of the three severe storms}

All the aforementioned three storms are related to monsoons other than typhoons. The meteorological factors for these storms are beyond the scope of this paper. This research focuses on the areal distribution of precipitation amount which is believed to

5 be more relevant to the evaluation of the performance of the slope safety system. Thus the maximum rolling rainfall values are estimated in different durations. According to the records from the automatic rain gauges, the maximum rolling rainfall among all the rain-gauge stations in each of the three events can be calculated. The corresponding peak values and stations are summarized in Table 1. The 22-24 July 1994 storm is the severest among the three storms with regard to the amounts of the maximum rolling 1 and $24 \mathrm{~h}$ rainfall. However, in terms of the maximum rolling $4 \mathrm{~h}$ rainfall, the 5-7 June 2008 storm is the most critical.

The scatter plots and contours of total rainfall amount for the three storms, interpolated using a triangular method, are shown in Fig. 3. The total precipitation amount of the 5-7 June 2008 storm is the smallest among the three events, while that of the 21-24 July 1994 storm is the largest due to its longer duration. However, the LPI value for the 5-7 June 2008 storm is 12, larger than those of the other two storms; that is, the 5-7 June 2008 storm is the severest one in terms of damage. One of the reasons is that the variability of spatial and temporal distribution of the storm affects both the infiltration dynamics of the surface soil and the water levels above and below the ground surface. The entire hydrological system is governed by the spatial and temporal distribution of rainfall.

\section{Methodology of spatial analysis}

Owing to the hilly terrain and varying meteorological conditions in Hong Kong, the 25 spatial and temporal distribution of rainfall exhibits high variability. It is hard to determine the spatial characteristics by a physical model. Instead a three-step approach is
HESSD

12, 6981-7021, 2015

Spatial

characteristics of

severe storms in

Hong Kong

L. Gao and L. M. Zhang

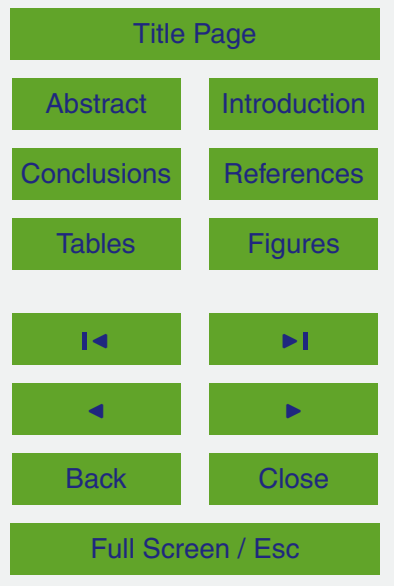

Printer-friendly Version

Interactive Discussion 
adopted in this paper. The first step is to recognize the spatial structure of precipitation amounts as represented by semivariograms in different durations, which are the most important characteristics of a storm event. The second step is to assess the distribution of the rainfall amount in a certain duration in spatial domain via surface trend fitting.

5 The third step is to determine the spatial correlation of the detrended residuals through geostatistics.

\subsection{Semivariance analysis}

The measured rainfall amounts in terms of maximum rolling rainfall are correlated spatially within a short distance. The semivariogram (e.g., Goovaerts, 1997) is

10 a traditional method for studying the correlation structure. The semivariance is calculated as half of the average squared difference between sample pairs, whose increments depend only on the difference between sample values other than the locations. The semivariogram function is defined by the semi-variance over a lag vector $h$,

${ }_{15} \quad \gamma(\boldsymbol{h})=\frac{1}{2 N(\boldsymbol{h})} \sum_{\alpha=1}^{N(\boldsymbol{h})}\left[z\left(u_{\alpha}+\boldsymbol{h}\right)-z\left(u_{\alpha}\right)\right]^{2}$

where $\boldsymbol{h}$ is a lag vector representing the separation distance between two spatial locations; $N(\boldsymbol{h})$ is the number of the sample pairs under consideration; $z$ is the regionalized value of rainfall depth and assumed to be stationary; $\left(\boldsymbol{u}_{\alpha}+\boldsymbol{h}\right)$ and $\boldsymbol{u}$ are position vectors, in form of spatial coordinates of $x, y$ in a two-dimensional case.

The variogram will reach a sill at a given range unless the dataset is non-stationary (Goovaerts, 1997). In fact, it is quite rare for the spatial data set to be absent of spatial correlation. How to use a semivariogram to detect the spatial structure can be found in numerous publications (e.g., Webster and Oliver, 2007; Dasaka and Zhang, 2012).

Simple mathematical models are often used to fit the experimental variogram. The
HESSD

$12,6981-7021,2015$

Spatial

characteristics of

severe storms in

Hong Kong

L. Gao and L. M. Zhang

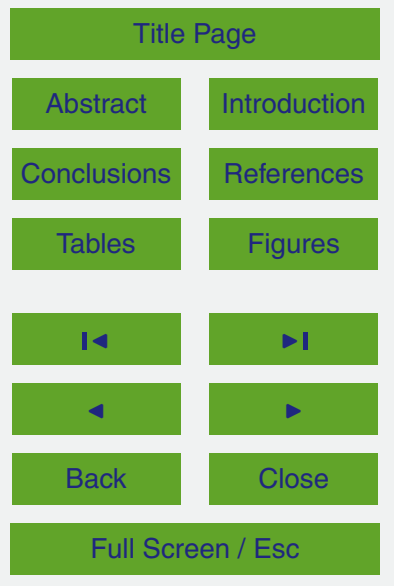

Printer-friendly Version

Interactive Discussion 
2014):

$\gamma(h)=C\left[1-\exp \left(\frac{-3 h}{a}\right)\right]$

HESSD

12, 6981-7021, 2015

where $\gamma$ is the semivariance; $h$ is the separation distance; $C$ is the sill; $a$ is the range. The parameters of the sill and the range can be used to describe the spatial structure. 5 The nugget effect is not considered in this study.

In an isotropic case, the semivariance values depend only on the separation distance $|h|$. The rainfall data pairs are assumed to be similar in all directions. The resulting semivariogram is called omnidirectional. For illustration, the variograms for the maximum rolling 4 and $24 \mathrm{~h}$ rainfall of the 5-7 June 2008 storm are shown in Fig. 5.

10 The semivariogram indicates the connectivity of rainfall data pairs. The range value obtained from the fitting model reflects the geometric patterns of spatial distribution. The semivariance of the maximum rolling $4 \mathrm{~h}$ rainfall is smaller within a shorter separation distance $(10 \mathrm{~km})$, and has a longer range structure, which suggests better spatial connectivity of rainfall data pairs. Using the same procedure, the omnidirectional parameters of range and sill for the three storm events are obtained and listed in Table 2. According to previous studies (Goovaerts, 1997), a dataset is non-stationary if the semivariogram does not level off for large values of range. The results in Fig. 5 for the three storms level off quickly, especially for the storm events on 5-7 June 2008 and 17-22 August 2005. Thus the results agree with the assumption that the datasets 20 are stationary. The semivariance values of the 22-24 July 1994 storm are larger than those of the other two, indicating that the rainfall data in the 1994 storm varies more erratically in the spatial domain. The range values of the three events are within $16 \mathrm{~km}$ and believed to be related to terrain and meteorological conditions.

In the anisotropic case, the semivariance depends on vector $\boldsymbol{h}$ for given information of distance and orientation. A semivariogram is said to be anisotropic when its pattern varies with direction. Anisotropy is divided into two types; namely, geometric anisotropy and zonal anisotropy. It is said to be geometric when the directional semivariograms

Spatial

characteristics of

severe storms in

Hong Kong

L. Gao and L. M. Zhang

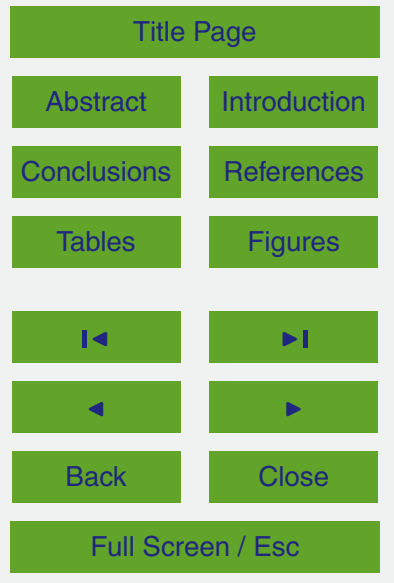

Printer-friendly Version

Interactive Discussion 
have the same shape and sill but different range values. In this study, the experimental semivariograms are calculated in the directions of North, $\mathrm{N} 45^{\circ} \mathrm{E}$, East, and $\mathrm{N} 135^{\circ} \mathrm{E}$ $\left(90^{\circ}, 45^{\circ}, 0^{\circ}\right.$, and $-45^{\circ}$ in anticlockwise direction). The directional semivariograms indeed have the similar shape and sill values, hence the anisotropy is considered to 5 be geometric. The range values of the three events in different durations are plotted against direction, which are shown in Figs. 6-8. Owning to the decreased data pairs, the directional semivariograms are noisier. Therefore, it does not tell anisotropy unless there is overwhelming evidence. Among the diagrams of range for the three storms, the data pairs of the 17-21 August 2005 storm have the smallest range. Except for the

10 maximum rolling $4 \mathrm{~h}$ rainfall of the 17-21 August 2005 storm, the patterns in the other three longer durations do not vary with direction substantially, and can be recognized as isotropic. While the spatial patterns of the other two events are found to vary with direction. The major directions are between 25 and $45^{\circ}$ in anticlockwise direction, which describe the direction of maximum continuity. In terms of duration, the patterns of the maximum rolling $4 \mathrm{~h}$ rainfall show strongest evidence of anisotropy compared with those of longer durations.

Regardless of the least data pairs, the range-diagram indicators of anisotropy for the 22-24 July 1994 storm tend to be erratic (Fig. 8). That may be caused by the extreme values of rainfall amount in the spatial domain in the Tai Mo Shan area. The semivariance analysis is not sufficiently robust, and the data needs to be transformed to reduce the influence of extreme values. A polynomial trend surface fitting method is then utilized to facilitate such transformation.

\subsection{Polynomial trend surface fitting}

A storm is a phenomenon with gradual geographical changes in space; the rainfall 25 amount can be simulated as a spatially correlated random field superimposed on a trend surface (Grimes and Pardo-Igúzquiza, 2010). Such an artificial rainfall trend surface can be used to represent design storms. One could comprehend that the rainfall is correlated with the local terrain and the design storm centres are likely to be

\section{HESSD}

12, 6981-7021, 2015

Spatial

characteristics of

severe storms in

Hong Kong

L. Gao and L. M. Zhang

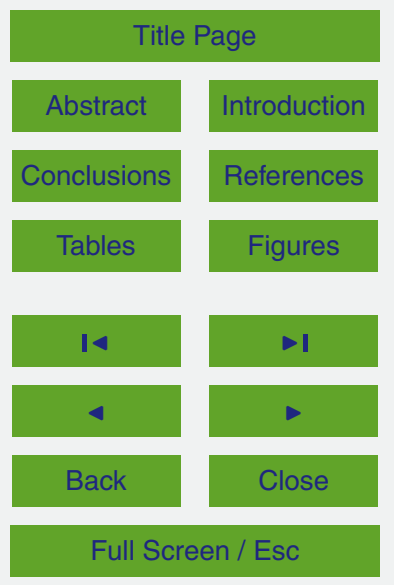

Printer-friendly Version

Interactive Discussion 
around the mountain peaks. Hong Kong has a relatively small area, and an individual storm is usually designed to have one or two centres for engineering design purposes (AECOM, 2014).

Based on random field theory (Vanmarcke, 1977), the trend surface is the expected 5 value of the precipitation distributed over the rainfall domain, while the residuals are stationary and not affected by any shift in the coordinate system. Thus the first step is to divide the spatial distribution into a trend surface and residuals by finding a trend surface fitting function. Though most natural processes like a storm exhibit spatial variability with complex trends, this paper uses a polynomial function for simplicity. 10 Denote observations of a storm as $z_{i}\left(x_{i}, y_{i}\right)(i=1,2, \ldots, n)$. The fitted values are $\hat{z}_{i}=\left(x_{i}, y_{i}\right)$ :

$z_{i}\left(x_{i}, y_{i}\right)=\hat{z}_{i}\left(x_{i}, y_{i}\right)+\varepsilon_{i}$

where $x$ and $y$ define the location; and $\epsilon_{i}$ are residuals. The second-order polynomial trend surface is:

$15 \hat{z}_{i}=a_{0}+a_{1} x_{i}+a_{2} y_{i}+a_{3} x_{i}^{2}+a_{4} x_{i} y_{i}+a_{5} y_{i}^{2}$

The coefficients, $a_{0}, a_{2}, \ldots, a_{5}$, are determined by minimizing the sum of the squares of the error term using the ordinary least squares (OLS) analysis (Journel and Huijbergts, 1978):

$Q=\min \sum_{i=1}^{n} \varepsilon_{i}^{2}=\min \sum_{i=1}^{n}\left[z_{i}\left(x_{i}, y_{i}\right)-\hat{z}_{i}\left(x_{i}, y_{i}\right)\right]^{2}$

20 The computed trend surfaces for the total rainfall amounts of the three storms and the detrended residuals are shown in Fig. 9. The residuals of the rainfall amounts in different durations are often assumed to be stationary. Due to inconsistencies caused by limited data, the fitting curves calculated by the OLS method may need to be adjusted. For example, the major axis directions of the trend surfaces for the 23 6991
HESSD

12, 6981-7021, 2015

Spatial

characteristics of

severe storms in

Hong Kong

L. Gao and L. M. Zhang

Title Page

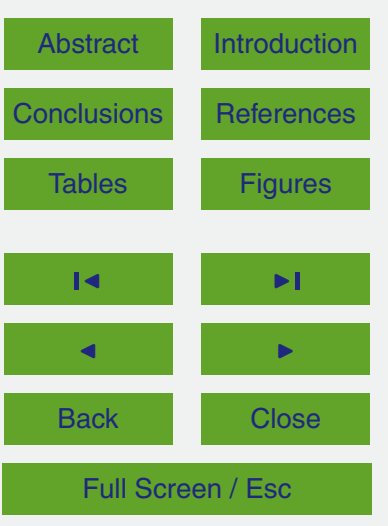

Printer-friendly Version

Interactive Discussion 
July 1994 storm change in different durations. According to the semivariogram analysis, the major axes tend to be northeast (NE) direction (Fig. 8). Therefore the major axes of the trend surfaces are adjusted to NE direction.

The trend surface and residuals of the maximum 4 and $24 \mathrm{~h}$ rolling rainfall of the 07 5 June 2008 storm are shown in Fig. 10. Taking the maximum $4 \mathrm{~h}$ rolling rainfall as an example, the trend surface is

$\hat{z}=-54607-0.0714 x+0.2127 y+\left(-1.6066 x^{2}+4.0885 x y-3.3886 y^{2}\right) \times 10^{-7}$

The peak point on the surface is $(761808,773375)$ in meter; the maximum $4 \mathrm{~h}$ rainfall on the trend surface is $425 \mathrm{~mm}$. The maximum points (extreme values) on the trend surfaces of the three storms are summarized in Table 3. The directions and lengths of the trend surfaces are summarized in Table 4. For an individual storm event, the maximum points of the trend surfaces are inside a relatively small range of $40 \mathrm{~km}$. The storm centre of each event on the trend surface agrees with the reality. The storm centres of the 07 June 2008 storm, the 17-21 August 2005 storm and the 23 July 1994 storm are at west Lantau Island, Shatin and Tai Mo Shan, respectively. The major directions of the spatial forms are between 25 and $45^{\circ}$ in the anticlockwise direction, which agree with the previous anisotropy analysis expressed in semivariograms. The long-axis directions and lengths of major and minor axis in different durations remain almost unchanged for each storm event. That is to say, the forms of the artificial surface trends for an individual storm show consistency in different durations, exhibiting geometrical regularity.

\subsection{Determination of scale of fluctuation}

A classical way to characterizing the spatial correlation is through an autocorrelation function (ACF), $\rho(h)$ (Fenton and Griffiths, 2008; Foresti and Seed, 2014). The autocorrelation describes the correlation between values of a same series. The autocorrelation $r(k)$ for lags $k=0,1, \ldots, m$, where $m$ is the maximum number of lags,

\section{HESSD}

12, 6981-7021, 2015

\section{Spatial}

characteristics of

severe storms in

Hong Kong

L. Gao and L. M. Zhang

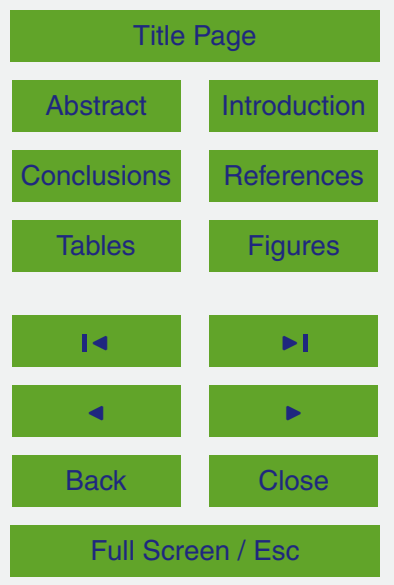

Printer-friendly Version

Interactive Discussion 
is evaluated by the following equation:

$r_{k}=\frac{\frac{1}{(N-k-1)} \sum_{i=1}^{N-k}\left(z_{i}-\bar{z}\right)\left(z_{i+k}-\bar{z}\right)}{\frac{1}{(N-1)} \sum_{i=1}^{N-k}\left(z_{i}-\bar{z}\right)^{2}}$

where, $z_{i}$ and $z_{i+k}$ are the detrended storm depths at locations $i$ and $i+k$, respectively; $N$ is the total number of the residuals; and $\bar{z}$ is the mean value of the residuals.

5 In order to assess the autocorrelation structure of the detrended storm amounts, it is necessary to perform regression analysis to fit the ACF. Among many correlation structures, the single exponential structure is the most common:

$\rho(h)=\exp (-2 h / \theta)$

where $h$ is the separation distance or lag; $\theta$ is the scale of fluctuation (SoF). 10 The correlation $\rho(h)$ decays exponentially with separation distance $h$. The negative autocorrelation coefficient will not be evaluated.

The autocorrelation functions in the horizontal direction of the maximum rolling 4 and $24 \mathrm{~h}$ rainfall residuals of the 07 June 2008 storm event explained by this exponential function are shown in Fig. 11. The values of $\theta$ can be obtained accordingly. Within 15 the scale of fluctuation, the rainfall property is strongly correlated. A smaller scale of fluctuation indicates more rapid fluctuations of the mean. The horizontal SoF value of the maximum rolling $24 \mathrm{~h}$ rainfall residuals of the 07 June 2008 storm is $8.5 \mathrm{~km}$, smaller than that of the maximum rolling $4 \mathrm{~h}$ rainfall $(12.2 \mathrm{~km})$.

Using the same procedure, the scale of fluctuation is evaluated in the directions of 20 East, $\mathrm{N} 45^{\circ} \mathrm{E}$, North, and $\mathrm{N} 135^{\circ} \mathrm{E}$ for each storm. The SoF values and ellipse-fitting curves for the three storms in different durations are calculated and plotted in Figs. 1214. The directions and semi-lengths of the axes of scale of fluctuation are summarized in Table 5. If the SoF values are direction independent, the residuals are considered to be isotropic; otherwise they are considered to be anisotropic. The SoF values of the maximum rolling 12, 24 and $36 \mathrm{~h}$ rainfall amounts of the 17-21 August 2005 rainfall

HESSD

12, 6981-7021, 2015

Spatial

characteristics of

severe storms in

Hong Kong

L. Gao and L. M. Zhang

Title Page

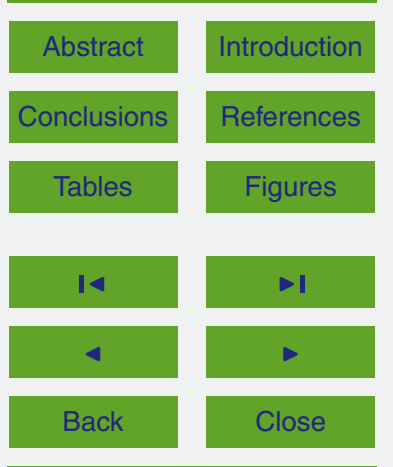

Full Screen / Esc

Printer-friendly Version

Interactive Discussion 
residuals show strongest anisotropy. As expected, if the original rainfall amounts are isotropic, the isotropy of the detrended residuals will be influenced by the detrending transformation. The residuals of both the 5-7 June 2008 and 22-24 July 1994 storms do not show overwhelming evidence of anisotropy. Except for the 17-21 August 2005 5 storm, all of the SoF values are within $25 \mathrm{~km}$. Regardless of the variations of the principal axis direction, the minor-axis lengths of the SoF values remain around $7 \mathrm{~km}$ (Table 5). The threshold of the SoF values are results of the interaction between meteorological factors and the local terrain. As the duration becomes longer, the SoF values tend to be smaller. The residuals of the maximum rolling $4 \mathrm{~h}$ rainfall still show

\section{Spatial characteristics of Hong Kong storms}

\subsection{Geometric spatial form}

Though rainfall varies over space, the rainfall amount of a particular storm in terms of maximum rolling rainfall can be fitted by a polynomial function. The spatial form of the rainfall amount can be represented by a rotated ellipsoid with only one centre. Such an artificial spatial form may exhibit geometrical regularity. For each storm, the trend surfaces in different durations show good consistency in the shape parameters in terms of the peak point, long-axis direction and axis length. The peak points on the trend surfaces of the three storms are located in a relatively small range. The long-axis directions of the spatial forms of each event in different durations almost remain unchanged between 25 and $45^{\circ}$. The lengths of the major and minor axes for an individual storm show consistency. As to the long-axis direction of the 23 July 1994 event, which is set to be $\mathrm{N} 45^{\circ} \mathrm{E}$, the experimental semivariograms in the direction of $\mathrm{N} 45^{\circ} \mathrm{E}$ tend to be erratic. On the contrary, the SoF values of the detrended residuals seem to be regular. Therefore the long-axis adjustment for the trend surface seems to be reasonable. Detrending transformation is necessary for the data containing extreme

Spatial

characteristics of

severe storms in

Hong Kong

L. Gao and L. M. Zhang

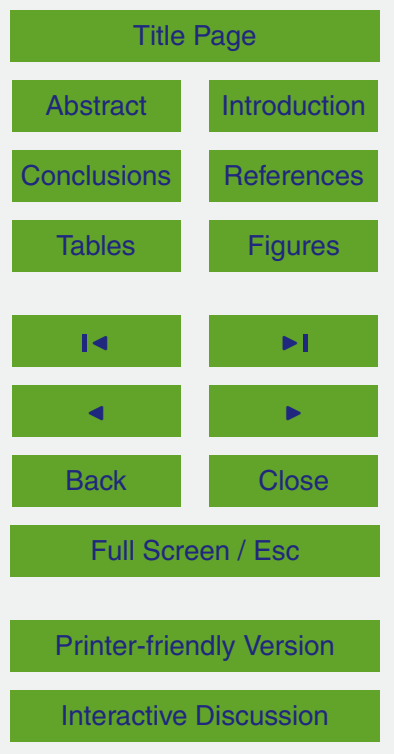


values in the spatial domain, rather than for the data showing good isotropy. It is not sufficiently robust to use only one method in the spatial rainfall analysis.

According to the $24 \mathrm{~h}$ PMP updating study (AECOM 2014), an elliptical isohyet as a generalized convergence pattern is recommended. For storms cantered at Tai Mo 5 Shan, the orientation of $22.5^{\circ}\left(\mathrm{N} 67.5^{\circ} \mathrm{E}\right)$ is found to be the most critical. This is believed to be related to the local terrain. The two highest mountain peaks in Hong Kong are Tai Mo Shan (Near rain gauge N14) and Lantau Peak (Near rain gauge N21), with peak elevations of 957 and $934 \mathrm{~m}$ above the sea level, respectively. The topography determines the geometric-shape characteristics (e.g., agglomerate and local gradient) of rainfall in the spatial domain.

\subsection{Spatial continuity and variability}

The spatial-variation patterns of the original data pairs and detrended residuals are quantified by the semivariogram and autocorrelation analysis, respectively. Generally speaking, a smaller semivariance indicates better spatial continuity of the data pairs.

15 According to the isotropic and anisotropic analyses, the semivariance values of the 2224 July 1994 storm are larger than those of the other two, suggesting that the rainfall data varies more erratically in the spatial domain. In reality, the areal distribution of the storm on 21-24 July 1994 was indeed uneven. There were extreme precipitation values concentrating near the peak of Tai Mo Shan.

20 Regarding the polynomial-detrended residuals, the overall SoF values of the 17-21 August 2005 storm are the largest, especially along $\mathrm{N} 45^{\circ} \mathrm{E}$. Since greater SoF values indicate smaller variability, the direction of $\mathrm{N} 45^{\circ} \mathrm{E}$ can be recognized as the maximum continuity.

\subsection{Correlation structure}

25 The spatial connectivity can be assessed by the range and SoF values. The omnidirectional ranges of the three storm events are estimated to be within $16 \mathrm{~km}$.
HESSD

12, 6981-7021, 2015

Spatial

characteristics of

severe storms in

Hong Kong

L. Gao and L. M. Zhang

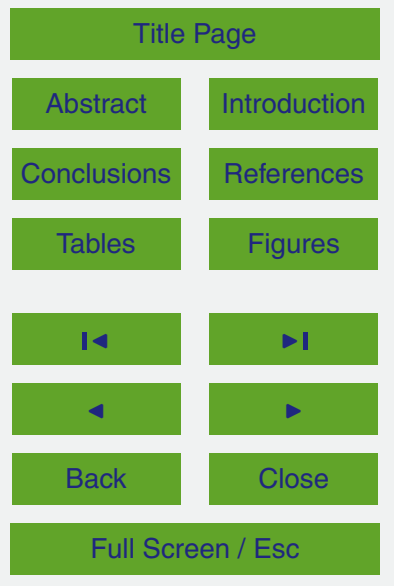

Printer-friendly Version

Interactive Discussion 
The data pairs of the 17-21 August 2005 storm have the smallest range according to the isotropic and anisotropic analyses.

The SoF values are observed to be smaller in longer durations. A smaller scale of fluctuation indicates more rapid fluctuations of the mean. The maximum rolling $4 \mathrm{~h}$ 5 rainfall shows best spatial continuity indicated by the largest range values. When the rolling rainfall duration is small, the area of intense rainfall is large. As the rolling rainfall duration becomes longer, the rainfall in the spatial domain will become more uneven, hence the SoF values will become smaller.

According to Figs. $6-8$ and $12-14$, all of the SoF values are within $25 \mathrm{~km}$ except 10 for the 12, 24 and $36 \mathrm{~h}$ scenarios of the 17-21 August 2005 storm. Nevertheless, the range values of these three scenarios are less than $25 \mathrm{~km}$. Hence a reasonable upper threshold for the spatial connectivity is estimated to be $25 \mathrm{~km}$. On the other hand, the minor axes of the SoF values are between 5 and $8 \mathrm{~km}$. The lower limit of the SoF values of the rainfall data is considered to be $5 \mathrm{~km}$. Therefore, the rainfall amount in Hong Kong 15 is observed to be strongly spatially correlated within $5 \mathrm{~km}$, whose spatial continuity is smaller than $25 \mathrm{~km}$. These threshold SoF values are governed by interactions between meteorological factors and the local terrain.

\subsection{Spatial anisotropy}

The spatial anisotropy is illustrated by both the surface trend and the range diagrams. 20 Actually the major principal directions of both are between $\mathrm{N} 45^{\circ} \mathrm{E}$ and $\mathrm{N} 65^{\circ} \mathrm{E}$, which describe the direction of maximum continuity. According to the range diagrams, the patterns of the maximum rolling $4 \mathrm{~h}$ rainfall show strongest evidence of anisotropy compared with those of the maximum rolling 12, 24 and $36 \mathrm{~h}$ rainfall. Based on the semivariance analysis, the spatial patterns of the 17-21 August 2005 storm do not vary 25 with direction generally, and can be recognized as isotropic except for the maximum rolling $4 \mathrm{~h}$ rainfall. The spatial distributions of different storms in a certain area are affected by topography and may exhibit spatial anisotropy.
HESSD

12, 6981-7021, 2015

Spatial

characteristics of

severe storms in

Hong Kong

L. Gao and L. M. Zhang

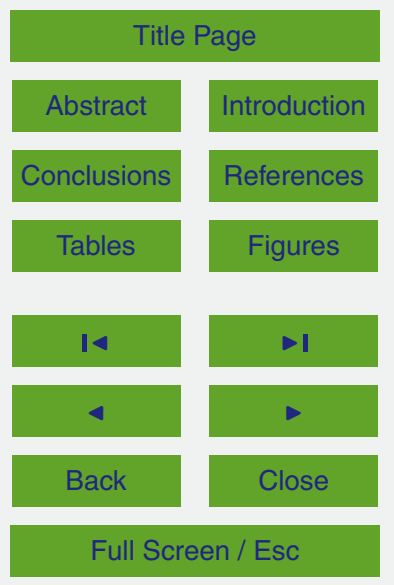

Printer-friendly Version

Interactive Discussion 


\subsection{Comparison with the spatial structure of annual maximum daily rainfall}

The spatial structure of annual maximum daily rainfall using the variogram model provides information for rainfall designs from another point of view. According to the study conducted by Jiang and Tung (2014), the spatial variability represented by

5 a variogram is used to establish the rainfall depth-duration-frequency relationships. By normalising the indicator semivariogram by the variance of the indicator data, the normalised semivariances of the mean annual maximum daily rainfall and the maximum rolling $24 \mathrm{~h}$ rainfall of the three storms are shown in Fig. 15. Based on the samples and fitted exponential variogram model, the corresponding value of the range of the mean of annual maximum daily rainfall was $7.1 \mathrm{~km}$, which is close to the omnidirectional range values of the maximum rolling $24 \mathrm{~h}$ rainfall for the storms, particularly those for the 2008 storm and the 2005 storm. Thus, given a severe storm whose spatial distribution is relatively smooth, the range value will be close to that of the annual maximum daily rainfall.

\section{Conclusions}

The spatial characteristics of three severe storms in Hong Kong are studied in this paper using geostatistical techniques. The cumulative rainfall depths in terms of maximum rolling rainfall in different durations are of particular importance in engineering designs and hence considered in this study. The spatial characteristics include the spatial forms and spatial correlations, which are needed in generating a random spatial distribution of rainfall depth. Based on the study, the following conclusions can be drawn:

1. Each of the spatial form of the amounts of maximum rolling rainfall in different durations can be represented by a rotated ellipsoid surface established using the ordinary least squares method. The shapes change slightly in different durations for an individual storm.

HESSD

12, 6981-7021, 2015

Spatial

characteristics of

severe storms in

Hong Kong

L. Gao and L. M. Zhang

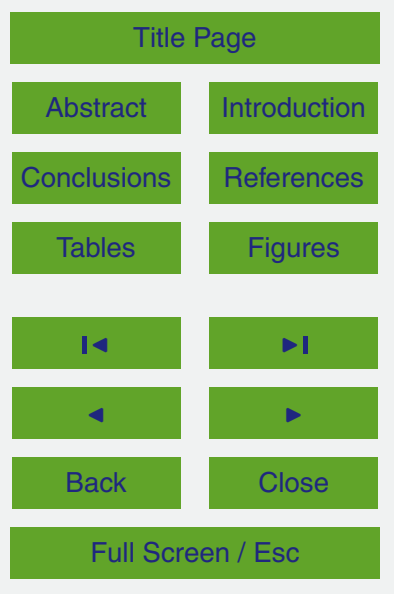

Printer-friendly Version

Interactive Discussion 
2. Both the major principal directions of the surface trend and range diagrams are between $\mathrm{N} 45^{\circ} \mathrm{E}$ and $\mathrm{N} 65^{\circ} \mathrm{E}$. In terms of duration, the patterns of the maximum rolling $4 \mathrm{~h}$ rainfall show strongest evidence of anisotropy compared with those of longer durations.

Acknowledgements. The authors would like to thank the Geotechnical Engineering Office (GEO) of the Civil Engineering and Development Department (CEDD) for providing the rainfall data described in this paper. This research is substantially supported by the Research Grants

\section{References}

AECOM Asia Company Limited: 24h PMP Updating Study. Agreement No. CE 13/2011 (GE), Geotechnical Engineering Office, Civil Engineering and Development Department, the Government of Hong Kong SAR, Hong Kong, 2011.

20 Bacchi, B. and Kottegoda, N.: Identification and calibration of spatial correlation patterns of rainfall, J. Hydrol., 165, 311-348, doi:10.1016/0022-1694(94)02590-8, 1995.

Barancourt, C., Creutin, J. D., and Rivoirard, J.: A method for delineating and estimating rainfall fields, Water Resour. Res., 28, 1133-1144, 1992.

Berne, A., Delrieu, G., and Boudevillain, B.: Variability of the spatial structure of intense Mediterranean precipitation, Adv. Water Resour., 32, 1031-1042, doi:10.1016/j.advwatres.2008.11.008, 2009.

HESSD

12, 6981-7021, 2015

Spatial

characteristics of

severe storms in

Hong Kong

L. Gao and L. M. Zhang

Title Page

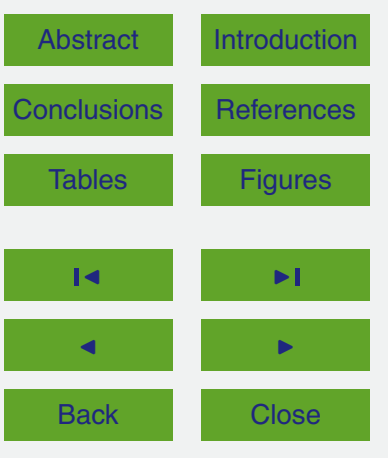

Full Screen / Esc

Printer-friendly Version

Interactive Discussion 
Bras, R. L. and Rodríguez-Iturbe, I.: Random Functions and Hydrology, Addison-Wesley, London, UK, 1985.

CEDD: Management of Natural Terrain Landslide Risk, Information Note 03/2008; 5, Civil Engineering and Development Department, the Government of Hong Kong SAR, Hong Kong, 5 available at: http://www.cedd.gov.hk/eng/publications/information_notes/doc/in_2008_03e. pdf, last access: 10 May 2015, 2008.

CEDD: Landslide Potential Index, Information Note 03/2009, Civil Engineering and Development Department, the Government of Hong Kong SAR, Hong Kong, available at: http://hkss.cedd.gov.hk/hkss/eng/landslipwarn/IN_2009_03.pdf, last access: 10 May 2015, 102009.

Chan, W. L.: Hong Kong Rainfall and Landslides in 1994, GEO report No. 54, Geotechnical Engineering Office, Civil Engineering and Development Department, the Government of Hong Kong SAR, Hong Kong, available at: http://www.cedd.gov.hk/eng/publications/geo_ reports/doc/er54.pdf, last access: 10 May 2015, 1995.

Chang, W. L. and Hui, T. W.: Probable Maximum Precipitation for Hong Kong, Reprint 482, Hong Kong Observatory, Hong Kong Observatory, the Government of Hong Kong SAR, Hong Kong, available at: http://www.hko.gov.hk/publica/reprint/r482.pdf, last access: 10 May 2015, 2001.

Dasaka, S. M. and Zhang, L. M.: Spatial variability of in situ weathered soil, Geotechnique, 62, $20 \quad 375-384,2012$.

Fenton, G. A. and Griffiths, D. V.: Risk Assessment in Geotechnical Engineering, John Wiley and Sons, Inc., Hoboken, New Jersey, 2008.

Foresti, L. and Seed, A.: The effect of flow and orography on the spatial distribution of the very short-term predictability of rainfall from composite radar images, Hydrol. Earth Syst. Sci., 18, 4671-4686, doi:10.5194/hess-18-4671-2014, 2014.

Foufoula-Georgiou, E. and Krajewski, W.: Recent advances in rainfall modelling, estimation, and forecasting, Rev. Geophys., 33, 1125-1137, 1995.

Goovaerts, P.: Geostatistics for Natural Resources Evaluation, Oxford Univ. Press, New York, 1997.

30 Goovaerts, P.: Geostatistical approaches for incorporating elevation into the spatial interpolation of rainfall, J. Hydrol., 228, 113-129, doi:10.1016/S0022-1694(00)00144-X, 2000.

HESSD

$12,6981-7021,2015$

Spatial

characteristics of

severe storms in

Hong Kong

L. Gao and L. M. Zhang

Title Page

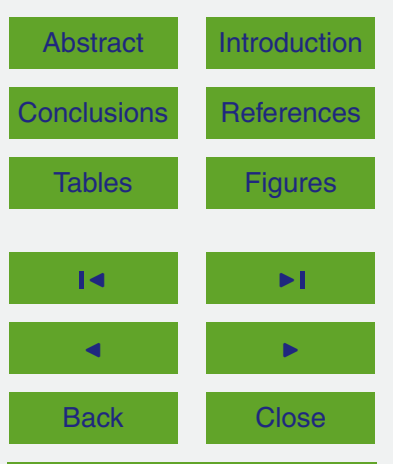

Full Screen / Esc

Printer-friendly Version

Interactive Discussion 
Greenpeace China: The "Climate Change Bill": Economic Costs of Heavy Rainstorm in Hong Kong, Greenpeace China, Hong Kong, available at: http://www.greenpeace.org/raw/content/ china/en/press/reports/black-rain-hong-kong.pdf last access: 1 February 2012, 2009.

Grimes, D. I. F. and Pardo-Igúzquiza, E.: Geostatistical analysis of rainfall geographical analysis, Geogr. Anal., 42, 136-160, doi:10.1111/j.15384632.2010.00787.x, 2010.

Jiang, P. and Tung, Y. K.: Incorporating daily rainfalls to derive rainfall DDF relationships at ungauged sites in Hong Kong and quantifying their uncertainty, Stoch. Env. Res. Risk A., 29, 45-62, doi:10.1007/s00477-014-0915-2, 2014.

Journel, A. G. and Huijbergts, C. J.: Mining Geostatistics, Academic Press, London, 1978.

Kong, H. S. W. and Ng, A. F. H.: Factual report on Hong Kong rainfall and landslides in 2005, GEO Report No. 223, Geotechnical Engineering Office, Civil Engineering and Development Department, the Government of Hong Kong SAR, Hong Kong, 2006.

Kyriakidis, P. C. and Journel, A. G.: Geostatistical space-time models: a review, Math. Geol., 31, 651-684, 1999.

Lebel, T. and Laborde, J. P.: A geostatistical approach for areal rainfall statistics assessment, Stoch. Hydrol. Hydraul., 2, 245-261, 1988.

Leung, J. K. Y. and Law, T. C.: Kriging analysis on Hong Kong rainfall data, HKIE Transactions, 9, 26-31, doi:10.1080/1023697X.2002.10667865, 2002.

Li, A. C. O., Lau, J. W. C., Cheung, L. L. K., and Lam, C. L. H.: Review of landslides in 2008, GEO Report No. 274, Geotechnical Engineering Office, Civil Engineering and Development Department, the Government of Hong Kong SAR, Hong Kong, 2009.

Mascaro, G., Deidda, R., and Hellies, M.: On the nature of rainfall intermittency as revealed by different metrics and sampling approaches, Hydrol. Earth Syst. Sci., 17, 355-369, doi:10.5194/hess-17-355-2013, 2013.

Matheron, G.: Les Variables Re'gionalise'es et Leur Estimation, Masson et Cie, Paris, 1965.

Panthou, G., Vischel, T., Lebel, T., Quantin, G., and Molinié, G.: Characterising the space-time structure of rainfall in the Sahel with a view to estimating IDAF curves, Hydrol. Earth Syst. Sci., 18, 5093-5107, doi:10.5194/hess-18-5093-2014, 2014.

Rodriguez-Iturbe, I. and Mejia, J.: The design of rainfall networks in time and space, Water Resour. Res., 10, 713-728, 1974.

Tam, K. H., Au, C. H., and Chang, W. L.: The severe rainstorms on 22-24 July 1994 in Hong Kong, Reprint 256, Hong Kong Observatory, Hong Kong Observatory, the Government of

\section{HESSD}

12, 6981-7021, 2015

Spatial

characteristics of

severe storms in

Hong Kong

L. Gao and L. M. Zhang

Title Page

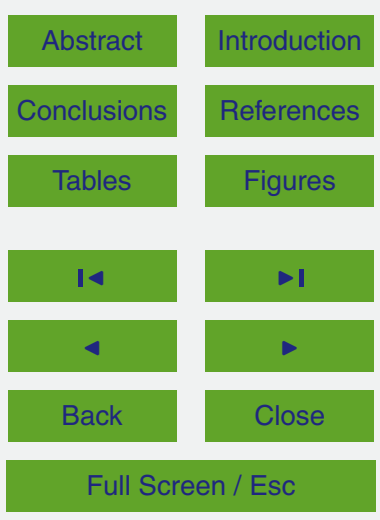

Printer-friendly Version

Interactive Discussion 
Hong Kong SAR, Hong Kong, available at: http://www.hko.gov.hk/publica/reprint/r256.pdf, last access: 10 May 2015, 1995.

Vanmarcke, E. H.: Probability modelling of soil profiles, J. Geotech. Eng.-ASCE, 103, 12271246, 1977.

5 Waymire, E. and Gupta, V. K.: The mathematical structure of rainfall representations: I. A review of the stochastic rainfall models, Water Resour. Res., 17, 1261-1272, 1981.

Webster, R. and Oliver, M. A.: Geostatistics for Environmental Scientists, John Wiley and Sons Ltd, England, 2007.

World Meteorological Organization: Manual on Estimation of Probable Maximum Precipitation 10 (PMP), WMO-No.1045, Geneva, 2009.

Spatial

characteristics of

severe storms in

Hong Kong

L. Gao and L. M. Zhang

Title Page

Abstract

Introduction

Conclusions

References

Tables

Figures

14

4

Back

Full Screen / Esc

Printer-friendly Version

Interactive Discussion 
Table 1. Values of maximum rolling rainfall of three storms in Hong Kong.

\begin{tabular}{|c|c|c|c|c|c|c|}
\hline \multirow[t]{2}{*}{ Duration } & \multicolumn{2}{|c|}{ 5-7 June 2008 storm } & \multicolumn{2}{|c|}{ 17-21 August 2005 storm } & \multicolumn{2}{|c|}{ 22-24 July 1994 storm } \\
\hline & $\begin{array}{l}\text { Amount } \\
(\mathrm{mm})\end{array}$ & Station & $\begin{array}{l}\text { Amount } \\
(\mathrm{mm})\end{array}$ & Station & $\begin{array}{l}\text { Amount } \\
(\mathrm{mm})\end{array}$ & Station \\
\hline $1 \mathrm{~h}$ & 154 & N21 & 82 & N25 & 212 & N14 \\
\hline $4 \mathrm{~h}$ & 384 & N19 & 174 & N18 & 365 & N14 \\
\hline $24 \mathrm{~h}$ & 623 & N19 & 570 & N01 & 956 & N14 \\
\hline 2 days & 672 & N19 & 768 & N01 & 1216 & N14 \\
\hline 4 days & 768 & N19 & 890 & N01 & 1450 & N14 \\
\hline
\end{tabular}

HESSD

12, 6981-7021, 2015

Spatial

characteristics of

severe storms in

Hong Kong

L. Gao and L. M. Zhang

Title Page

Abstract

Introduction

Conclusions References

Tables

Figures

14

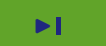

4

Back

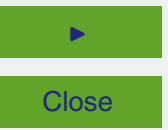

Full Screen / Esc

Printer-friendly Version

Interactive Discussion 
Table 2. Omnidirectional parameters of range and sill for three storms.

\begin{tabular}{lllllll}
\hline Duration & \multicolumn{2}{c}{ 5-7 June 2008 storm } & \multicolumn{2}{c}{$\begin{array}{r}\text { 17-21 } \\
\text { August } 2005 \\
\text { storm }\end{array}$} & \multicolumn{2}{c}{ 22-24 July 1994 storm } \\
& $\begin{array}{l}\text { Range } \\
(\mathrm{km})\end{array}$ & $\begin{array}{l}\text { Sill } \\
\left(\mathrm{mm}^{2}\right)\end{array}$ & $\begin{array}{l}\text { Range } \\
(\mathrm{km})\end{array}$ & $\begin{array}{l}\text { Sill } \\
\left(\mathrm{mm}^{2}\right)\end{array}$ & $\begin{array}{l}\text { Range } \\
(\mathrm{km})\end{array}$ & $\begin{array}{l}\text { Sill } \\
\left(\mathrm{mm}^{2}\right)\end{array}$ \\
\hline $4 \mathrm{~h}$ & 15.9 & 9054 & 6.3 & 1031 & 7.9 & 3192 \\
$12 \mathrm{~h}$ & 11.3 & 6250 & 5.5 & 2380 & 10.0 & 17804 \\
$24 \mathrm{~h}$ & 7.2 & 6472 & 6.8 & 9053 & 9.4 & 21607 \\
$36 \mathrm{~h}$ & 4.7 & 6601 & 7.6 & 13220 & 7.8 & 27515 \\
\hline
\end{tabular}

Spatial

characteristics of severe storms in Hong Kong

L. Gao and L. M. Zhang

Title Page

Abstract Introduction

Conclusions References

Tables

Figures

14

Back

Close

Full Screen / Esc

Printer-friendly Version

Interactive Discussion 
Table 3. Locations of maximum rainfall on the trend surfaces $(\mathrm{km})$.

\begin{tabular}{lccc}
\hline Duration & $5-7$ June 2008 storm & 17-21 August 2005 storm & 22-24 July 1994 storm \\
\hline $4 \mathrm{~h}$ & $(762,773)$ & $(822,815)$ & $(828,828)$ \\
$12 \mathrm{~h}$ & $(764,788)$ & $(825,822)$ & $(830,830)$ \\
$24 \mathrm{~h}$ & $(781,752)$ & $(829,819)$ & $(832,832)$ \\
$36 \mathrm{~h}$ & $(769,747)$ & $(830,820)$ & $(828,828)$ \\
\hline
\end{tabular}

HESSD

12, 6981-7021, 2015

Spatial

characteristics of

severe storms in

Hong Kong

L. Gao and L. M. Zhang

Title Page

Abstract

Introduction

Conclusions

References

Tables

Figures

14

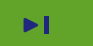

4

Back

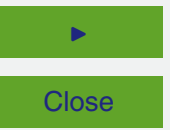

Full Screen / Esc

Printer-friendly Version

Interactive Discussion 
Table 4. Directions and lengths of the axes of trend surfaces.

\begin{tabular}{|c|c|c|c|c|c|c|c|c|c|}
\hline \multirow[t]{2}{*}{ Duration } & \multicolumn{3}{|c|}{ 5-7 June 2008 storm } & \multicolumn{3}{|c|}{ 17-21 August 2005 storm } & \multicolumn{3}{|c|}{ 22-24 July 1994 storm } \\
\hline & $\begin{array}{l}\text { Major } \\
\text { axis } \\
\text { direction } \\
\left(^{\circ}\right)\end{array}$ & $\begin{array}{l}\text { Major } \\
\text { axis } \\
\text { length } \\
(\mathrm{km})\end{array}$ & $\begin{array}{l}\text { Minor } \\
\text { axis } \\
\text { length } \\
(\mathrm{km})\end{array}$ & $\begin{array}{l}\text { Major } \\
\text { axis } \\
\text { direction } \\
\left(^{\circ}\right)\end{array}$ & $\begin{array}{l}\text { Major } \\
\text { axis } \\
\text { length } \\
(\mathrm{km})\end{array}$ & $\begin{array}{l}\text { Minor } \\
\text { axis } \\
\text { length } \\
(\mathrm{km})\end{array}$ & $\begin{array}{l}\text { Major } \\
\text { axis } \\
\text { direction } \\
\left(^{\circ}\right)\end{array}$ & $\begin{array}{l}\text { Major } \\
\text { axis } \\
\text { length } \\
(\mathrm{km})\end{array}$ & $\begin{array}{l}\text { Minor } \\
\text { axis } \\
\text { length } \\
(\mathrm{km})\end{array}$ \\
\hline $4 \mathrm{~h}$ & 33 & 252 & 60 & 44 & 102 & 53 & 45 & 86 & 57 \\
\hline $12 \mathrm{~h}$ & 27 & 253 & 65 & 30 & 97 & 58 & 45 & 74 & 54 \\
\hline $24 \mathrm{~h}$ & 25 & 269 & 71 & 34 & 83 & 53 & 45 & 105 & 60 \\
\hline $36 \mathrm{~h}$ & 28 & 386 & 65 & 32 & 84 & 54 & 45 & 128 & 68 \\
\hline
\end{tabular}

HESSD

12, 6981-7021, 2015

Spatial

characteristics of

severe storms in

Hong Kong

L. Gao and L. M. Zhang

Title Page

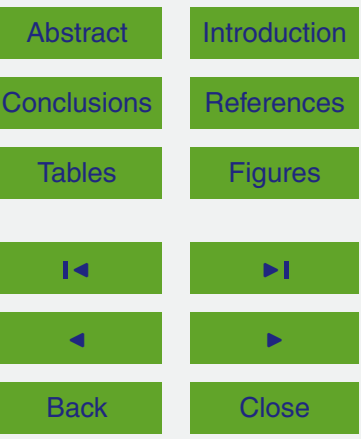

Full Screen / Esc

Printer-friendly Version

Interactive Discussion 
Table 5. Directions and semi-lengths of the axes of scale of fluctuation.

\begin{tabular}{|c|c|c|c|c|c|c|c|c|c|}
\hline \multirow[t]{2}{*}{ Duration } & \multicolumn{3}{|c|}{ 5-7 June 2008 storm } & \multicolumn{3}{|c|}{ 17-21 August 2005 storm } & \multicolumn{3}{|c|}{ 22-24 July 1994 storm } \\
\hline & $\begin{array}{l}\text { Major } \\
\text { axis } \\
\text { direction } \\
\left(^{\circ}\right)\end{array}$ & $\begin{array}{l}\text { Major } \\
\text { axis } \\
\text { length } \\
(\mathrm{km})\end{array}$ & $\begin{array}{l}\text { Minor } \\
\text { axis } \\
\text { length } \\
(\mathrm{km})\end{array}$ & $\begin{array}{l}\text { Major } \\
\text { axis } \\
\text { direction } \\
\left(^{\circ}\right)\end{array}$ & $\begin{array}{l}\text { Major } \\
\text { axis } \\
\text { length } \\
(\mathrm{km})\end{array}$ & $\begin{array}{l}\text { Minor } \\
\text { axis } \\
\text { length } \\
(\mathrm{km})\end{array}$ & $\begin{array}{l}\text { Major } \\
\text { axis } \\
\text { direction } \\
\left(^{\circ}\right)\end{array}$ & $\begin{array}{l}\text { Major } \\
\text { axis } \\
\text { length } \\
(\mathrm{km})\end{array}$ & $\begin{array}{l}\text { Minor } \\
\text { axis } \\
\text { length } \\
(\mathrm{km})\end{array}$ \\
\hline $4 \mathrm{~h}$ & 161 & 19 & 7 & 175 & 14 & 5 & 13 & 22 & 6 \\
\hline $12 \mathrm{~h}$ & 176 & 16 & 7 & 47 & 53 & 8 & 4 & 15 & 6 \\
\hline $24 \mathrm{~h}$ & 157 & 11 & 8 & 44 & 30 & 7 & 176 & 15 & 6 \\
\hline $36 \mathrm{~h}$ & 97 & 13 & 6 & 46 & 31 & 7 & 0 & 12 & 6 \\
\hline
\end{tabular}

HESSD

12, 6981-7021, 2015

Spatial

characteristics of

severe storms in

Hong Kong

L. Gao and L. M. Zhang

Title Page

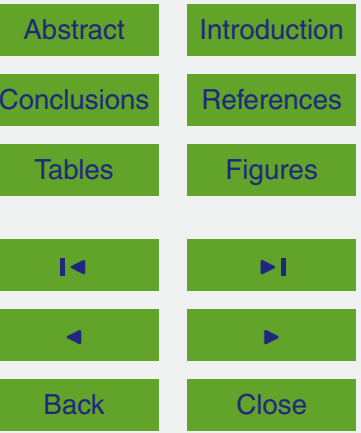

Full Screen / Esc

Printer-friendly Version

Interactive Discussion 


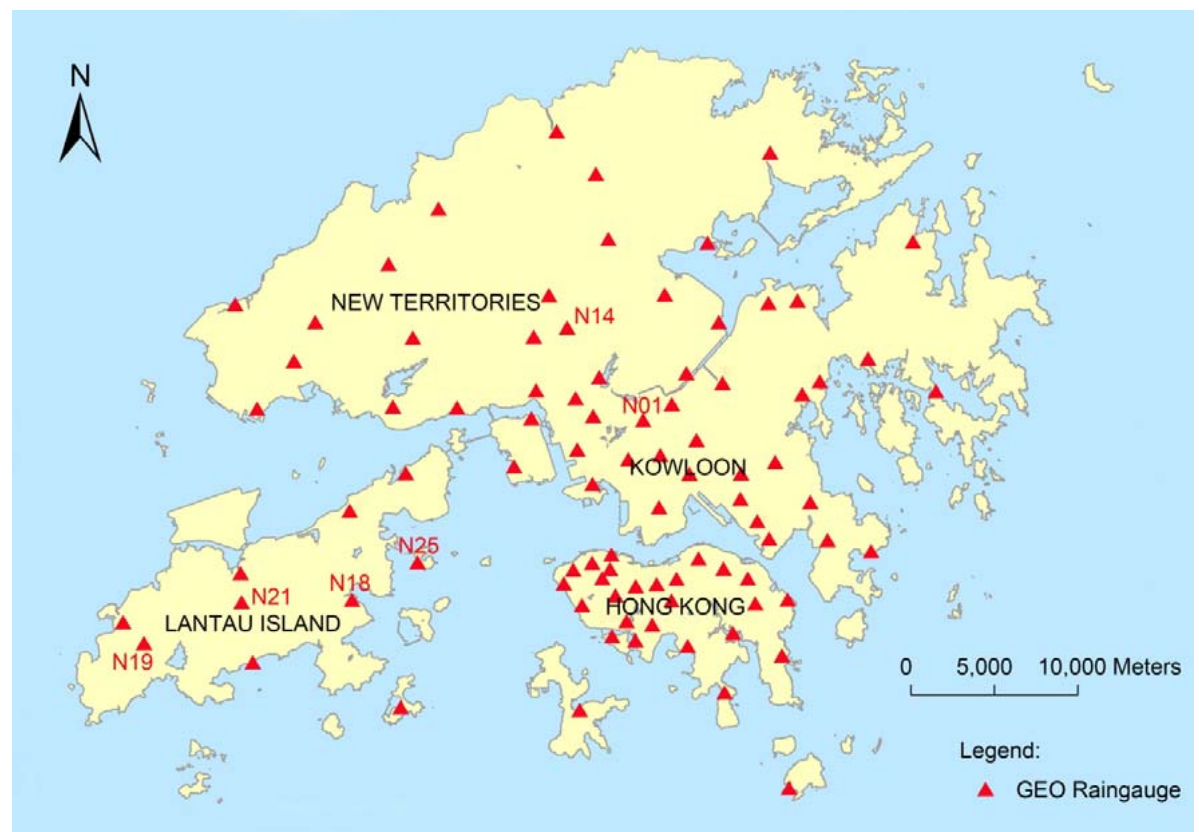

\section{HESSD}

12, 6981-7021, 2015

Spatial

characteristics of severe storms in

Hong Kong

L. Gao and L. M. Zhang

Title Page

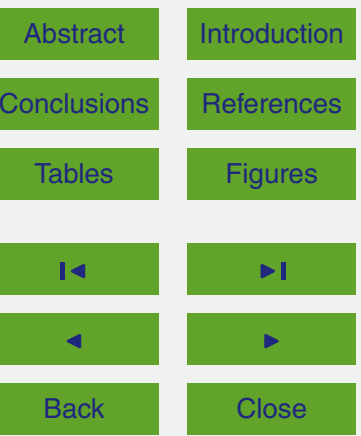

Full Screen / Esc

Figure 1. The GEO rain-gauge network in Hong Kong.

Printer-friendly Version

Interactive Discussion 
(a)

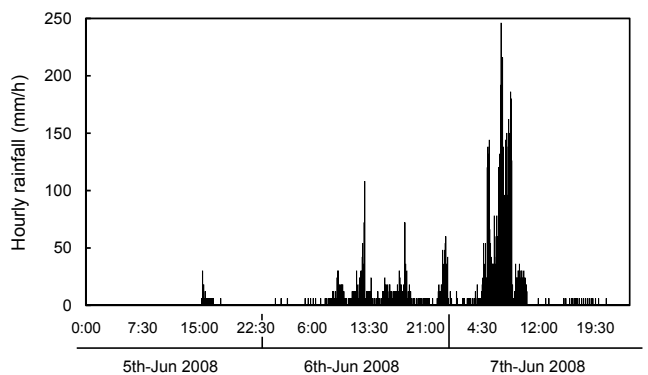

HESSD

12, 6981-7021, 2015

Spatial

characteristics of severe storms in

Hong Kong

(b)

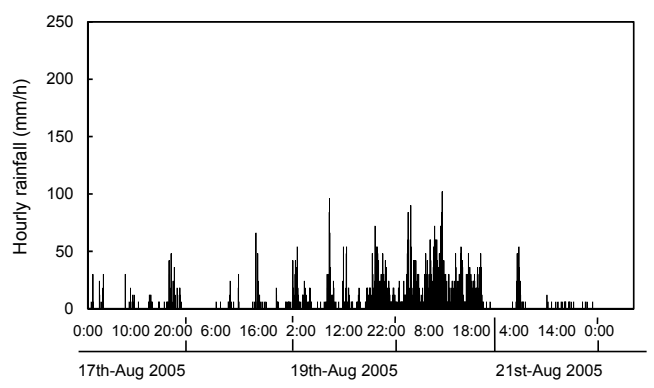

L. Gao and L. M. Zhang

Title Page

Abstract

Introduction

Conclusions

References

Tables

Figures

(c)

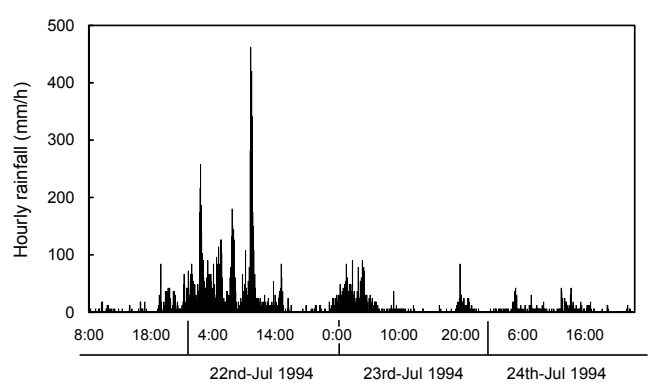

14

$>$ I

4

Back

Close

Full Screen / Esc

Printer-friendly Version

Figure 2. Hyetographs of three storms: (a) 5-7 June 2008 storm, Station N19; (b) 17-21 August 2005 storm, Station N01; (c) 22-24 July 1994 storm, Station N14. 

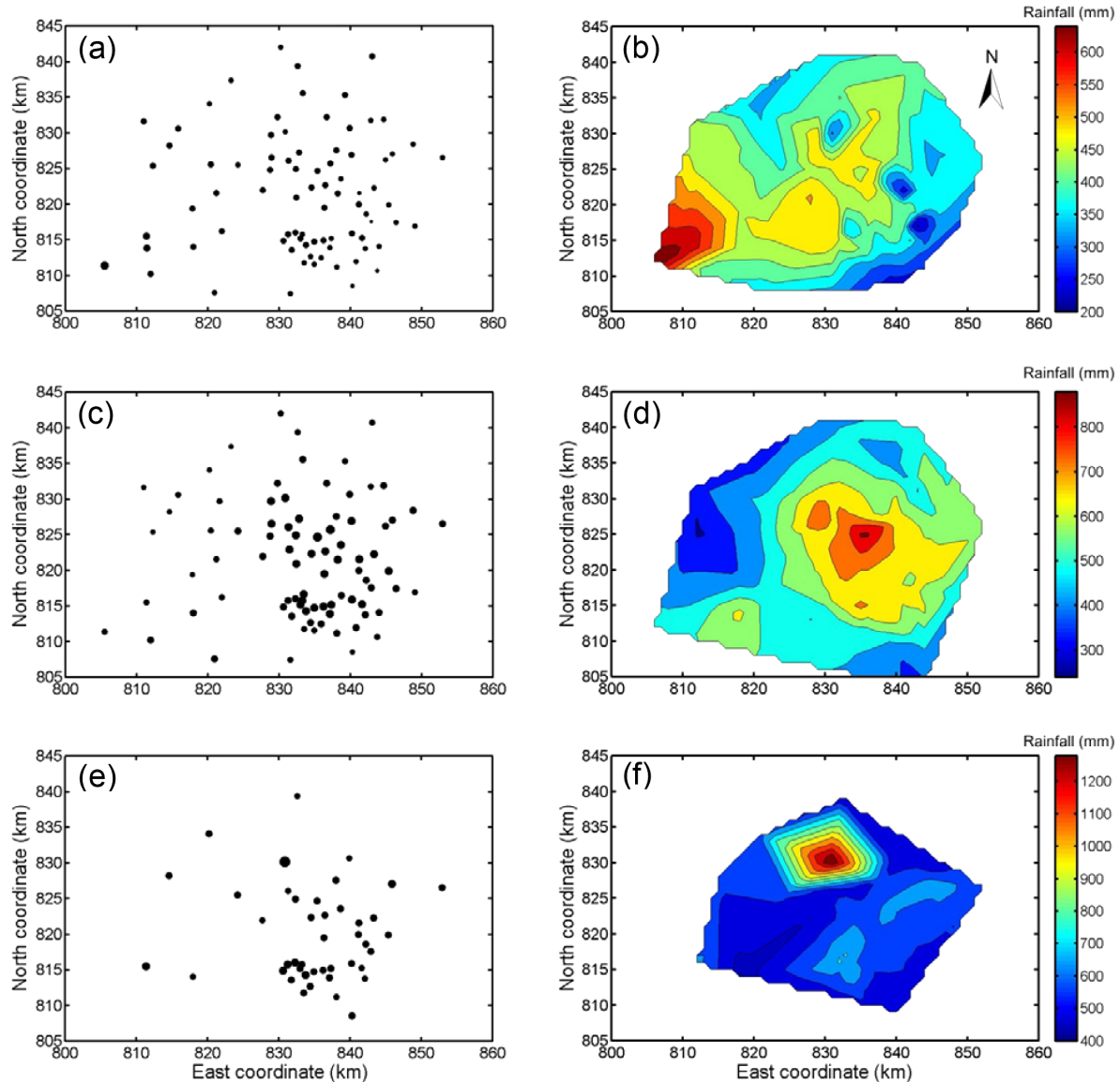

Figure 3. Scatter and spatial distribution of the total rainfall amount: (a and b) the 5-7 June 2008 storm; (c and d) the 17-21 August 2005 storm; (e and f) the 22-24 July 1994 storm.

\section{HESSD}

12, 6981-7021, 2015

\section{Spatial}

characteristics of severe storms in

Hong Kong

\section{Gao and L. M. Zhang}

Title Page

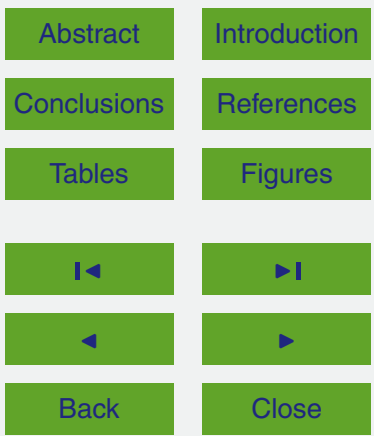

Full Screen / Esc

Printer-friendly Version

Interactive Discussion 
(a)

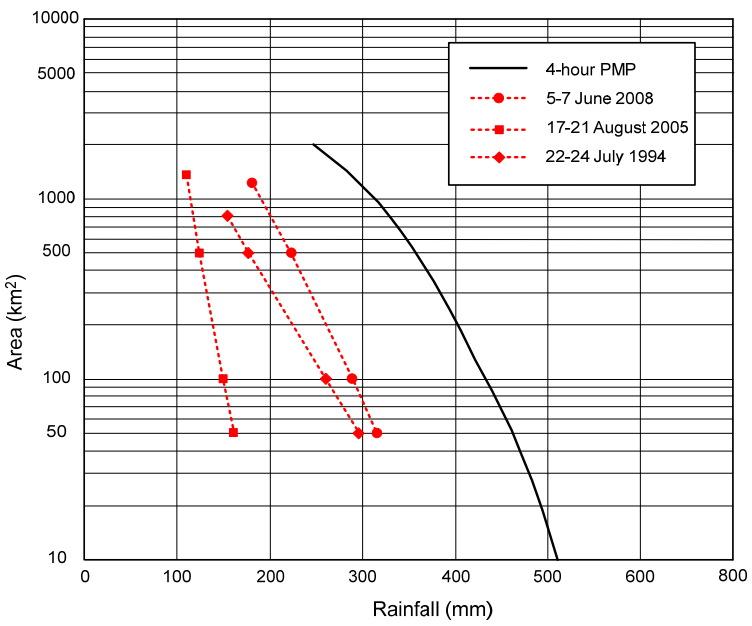

(b)

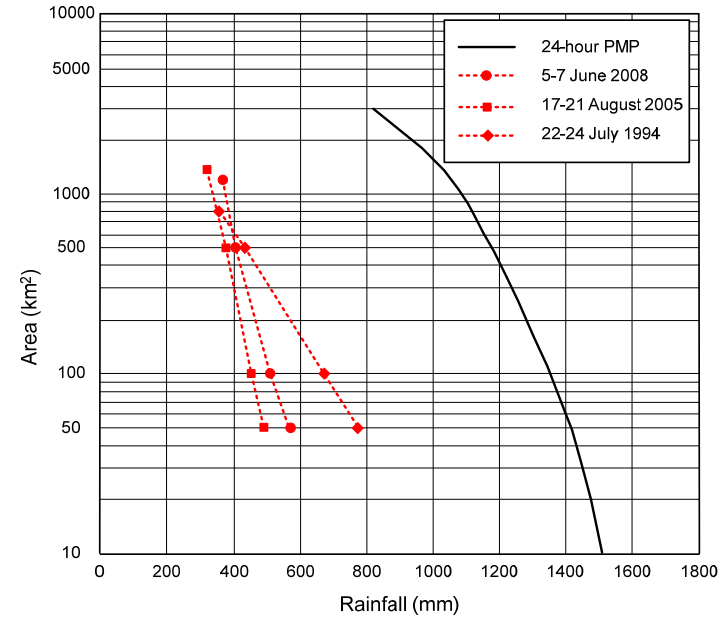

Figure 4. Magnitudes of the three storms characterized by (a) $4 \mathrm{~h} \mathrm{PMP,}$, and (b) $24 \mathrm{~h}$ PMP. 7010

\section{HESSD}

12, 6981-7021, 2015

\section{Spatial}

characteristics of severe storms in

Hong Kong

L. Gao and L. M. Zhang

Title Page

Abstract

Introduction

Conclusions References

Tables

Figures

14

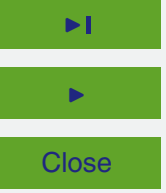

Back

Close

Full Screen / Esc

Printer-friendly Version

Interactive Discussion

(c) (i) 


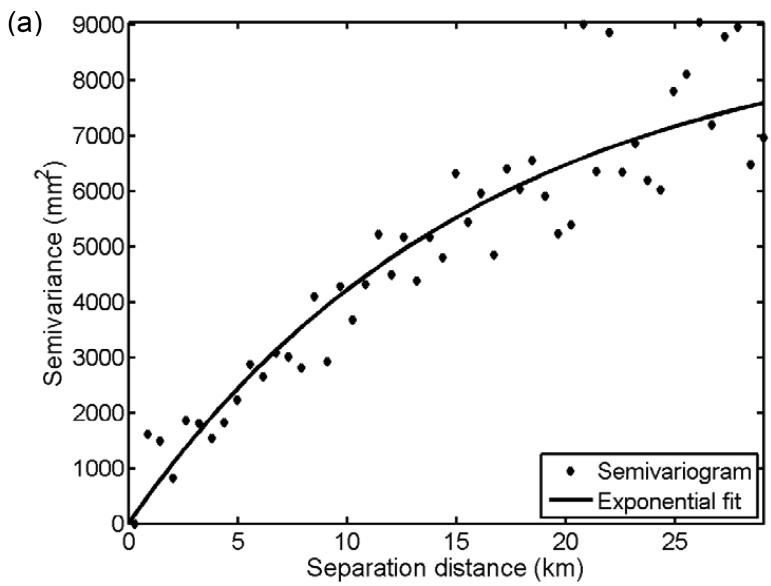

\section{HESSD}

12, 6981-7021, 2015

\section{Spatial}

characteristics of severe storms in

Hong Kong

L. Gao and L. M. Zhang

(b)

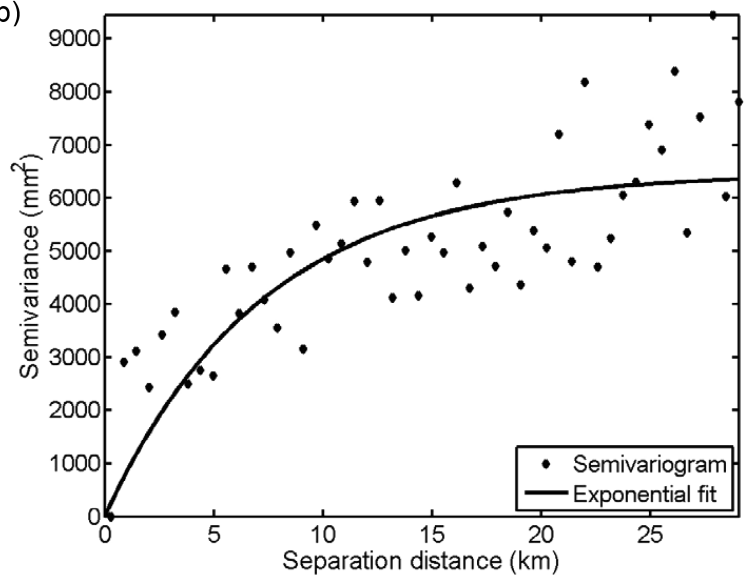

Title Page

Abstract

Introduction

Conclusions

References

Tables

Figures

14

Back

Close

Full Screen / Esc

Printer-friendly Version

Interactive Discussion

Figure 5. Semivariograms of (a) the maximum rolling $4 \mathrm{~h}$ rainfall and (b) the maximum rolling $24 \mathrm{~h}$ rainfall for the 5-7 June 2008 storm. 

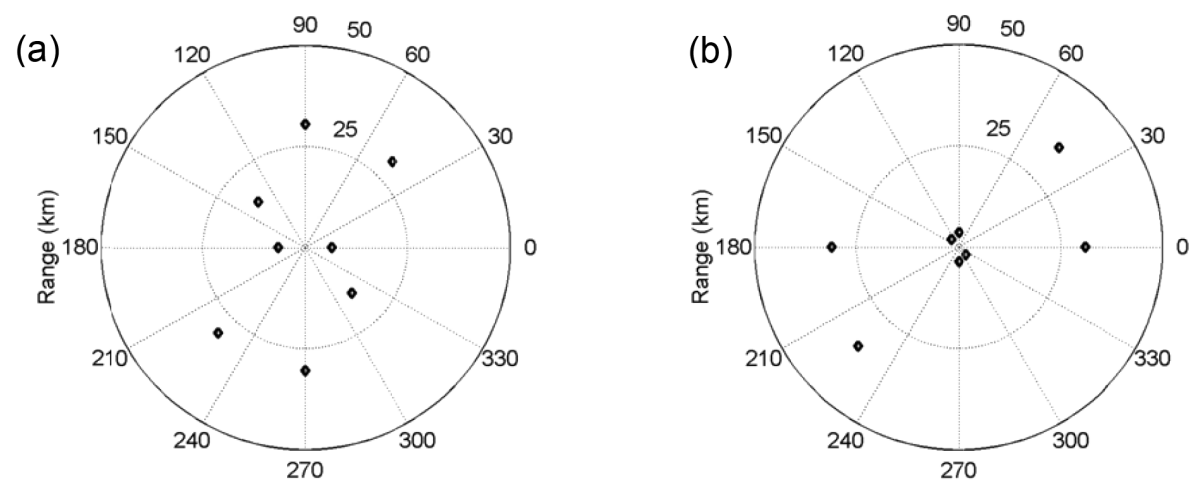

HESSD

12, 6981-7021, 2015

\section{Spatial}

characteristics of severe storms in

Hong Kong

L. Gao and L. M. Zhang
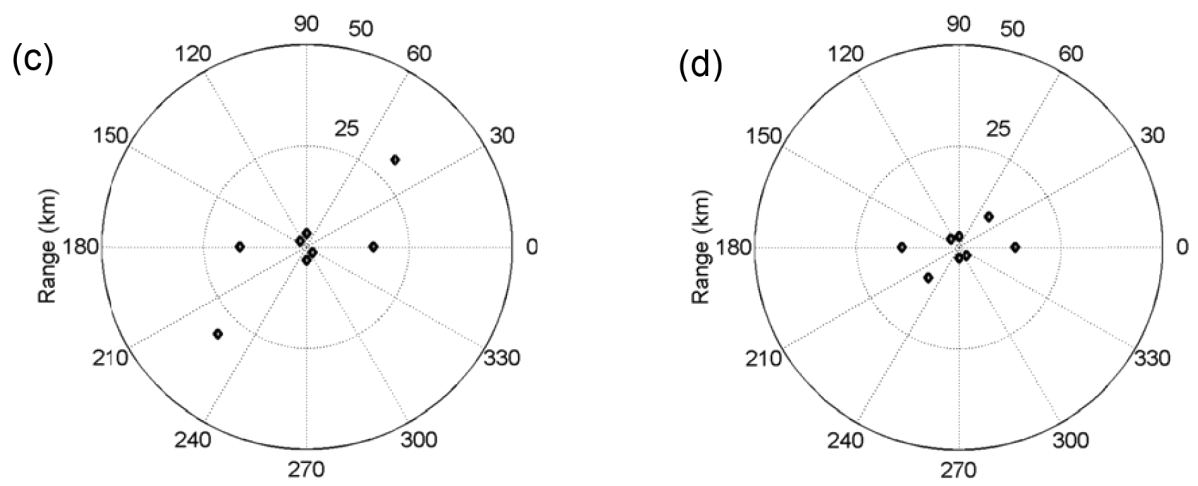

Title Page

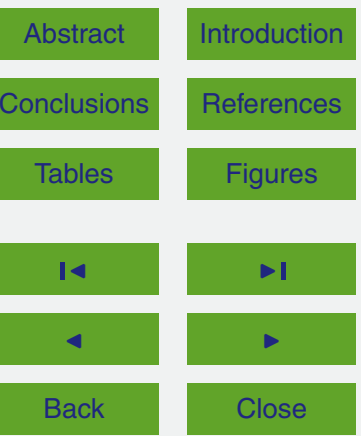

Full Screen / Esc

Figure 6. Range values for the 5-7 June 2008 storm: (a) maximum rolling $4 \mathrm{~h}$ rainfall; (b) maximum rolling $12 \mathrm{~h}$ rainfall; (c) maximum rolling $24 \mathrm{~h}$ rainfall; (d) maximum rolling $36 \mathrm{~h}$ rainfall.

Printer-friendly Version

Interactive Discussion 
(a)

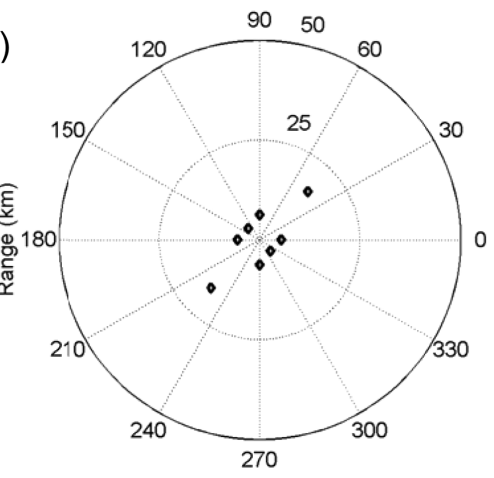

(c)

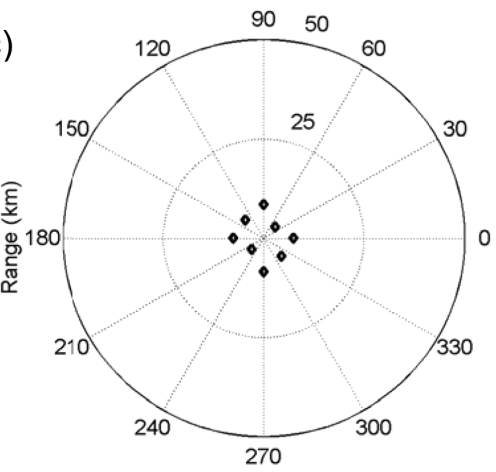

(b)

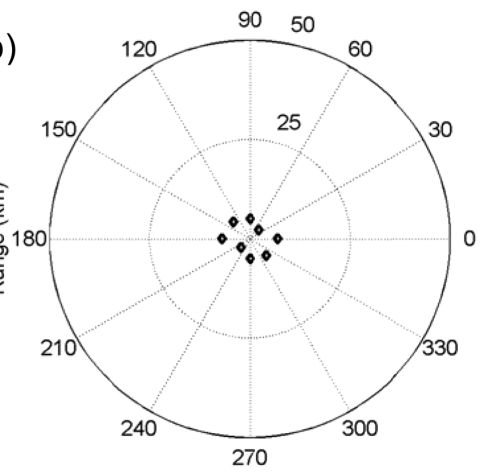

(d)

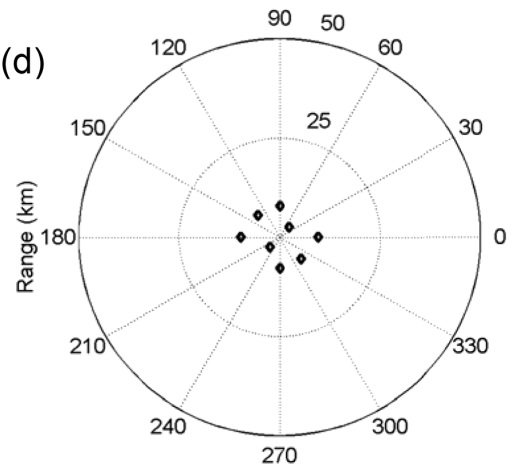

HESSD

12, 6981-7021, 2015

Spatial

characteristics of severe storms in

Hong Kong

L. Gao and L. M. Zhang

Title Page

Abstract

Introduction

Conclusions

References

Tables

Figures

14

Back

Close

Figure 7. Range values for the 17-21 August 2005 storm: (a) maximum rolling $4 \mathrm{~h}$ rainfall; (b) maximum rolling $12 \mathrm{~h}$ rainfall; (c) maximum rolling $24 \mathrm{~h}$ rainfall; (d) maximum rolling $36 \mathrm{~h}$ rainfall.

Full Screen / Esc

Printer-friendly Version

Interactive Discussion 

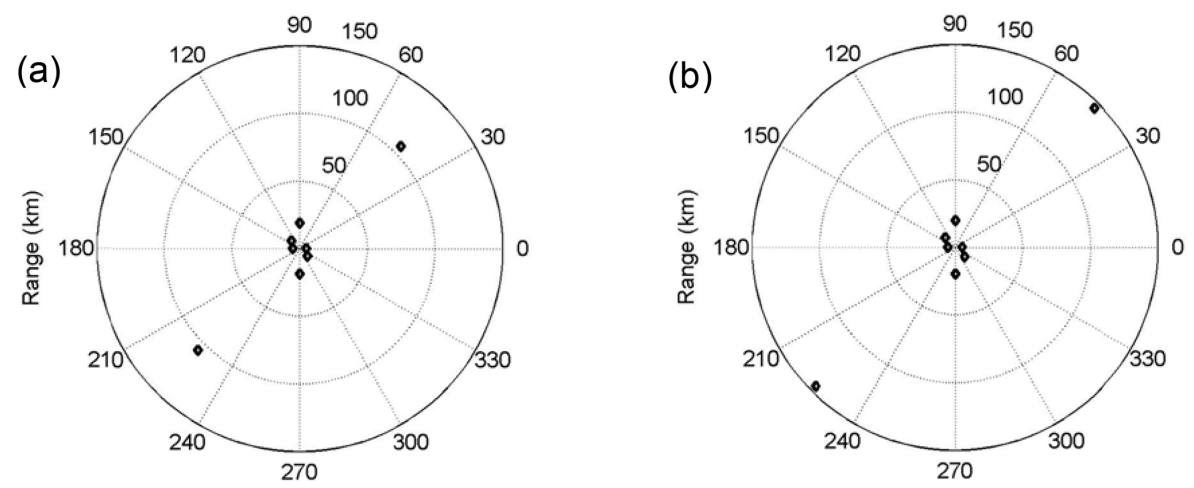

\section{HESSD}

12, 6981-7021, 2015

\section{Spatial}

characteristics of severe storms in

Hong Kong

L. Gao and L. M. Zhang

Title Page
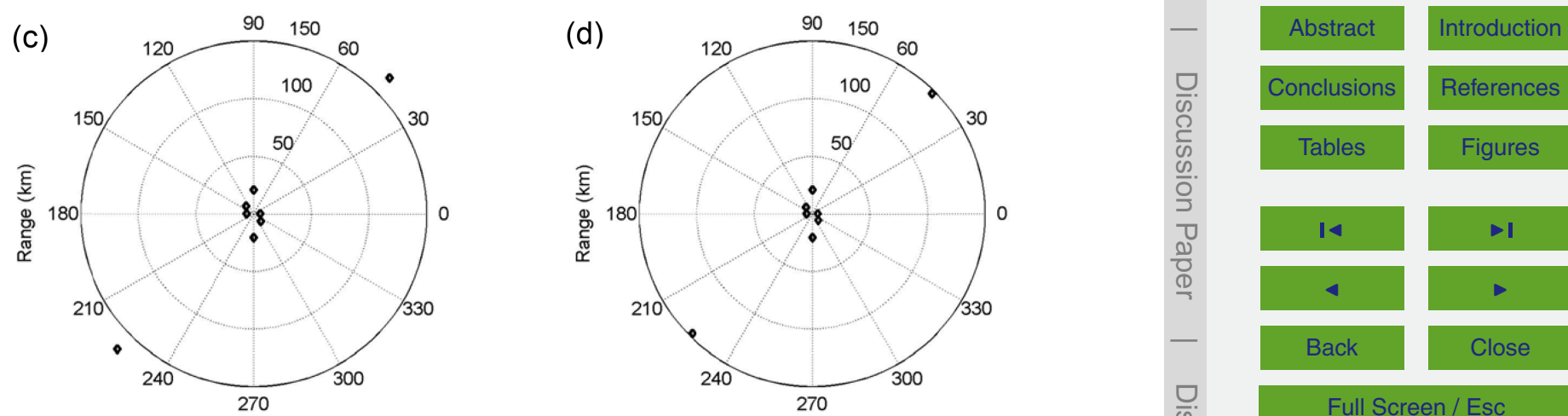

Full Screen / Esc

Figure 8. Range values for the 22-24 July 1994 storm: (a) maximum rolling $4 \mathrm{~h}$ rainfall; (b) maximum rolling $12 \mathrm{~h}$ rainfall; (c) maximum rolling $24 \mathrm{~h}$ rainfall; (d) maximum rolling $36 \mathrm{~h}$ rainfall.

Printer-friendly Version

Interactive Discussion 

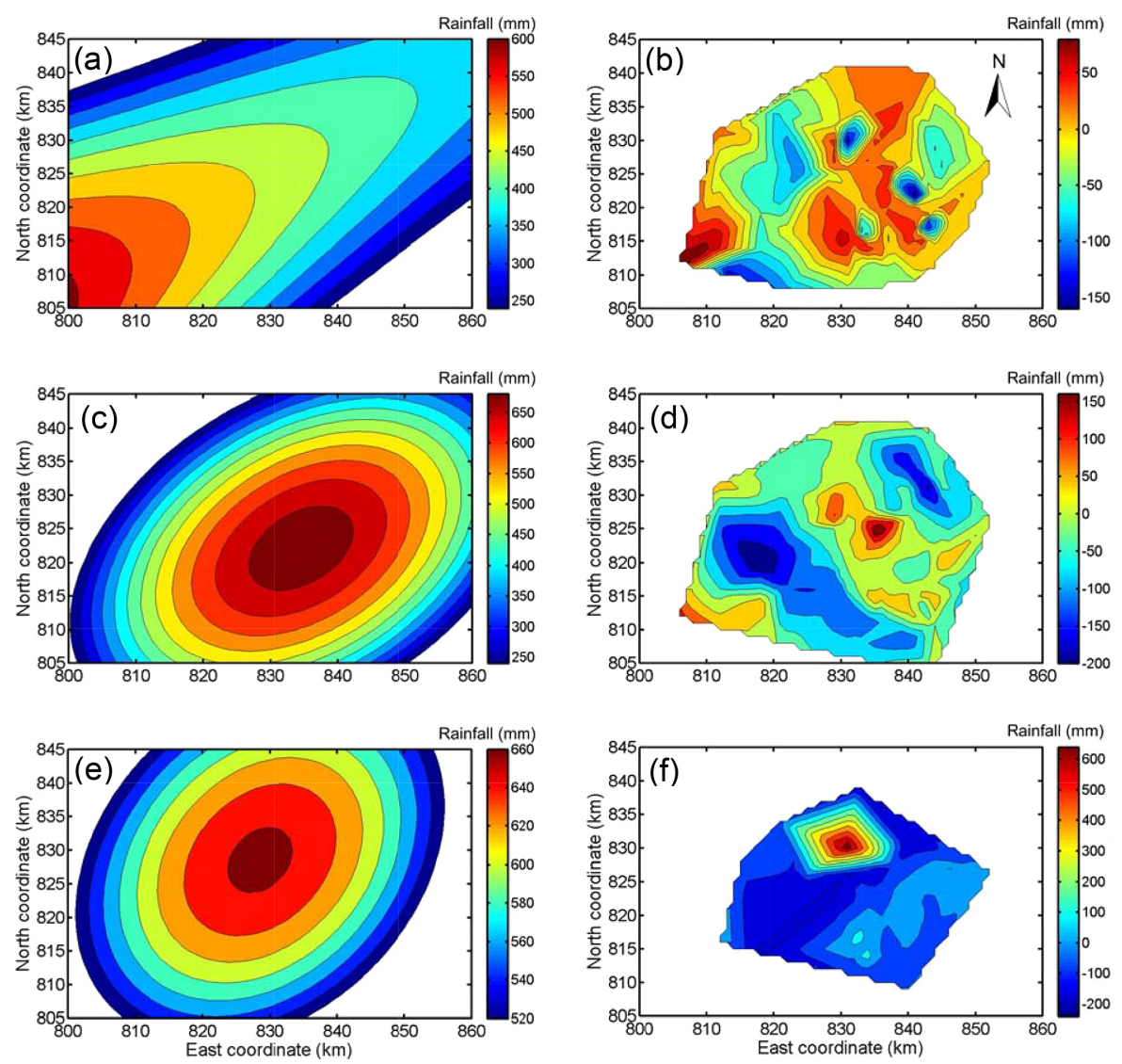

Figure 9. Trend surfaces and residuals of the total rainfall amounts: (a and b) the 5-7 June 2008 storm; (c and d) the 17-21 August 2005 storm; (e and f) the 22-24 July 1994 storm.

\section{HESSD}

12, 6981-7021, 2015

\section{Spatial}

characteristics of severe storms in

Hong Kong

L. Gao and L. M. Zhang

Title Page

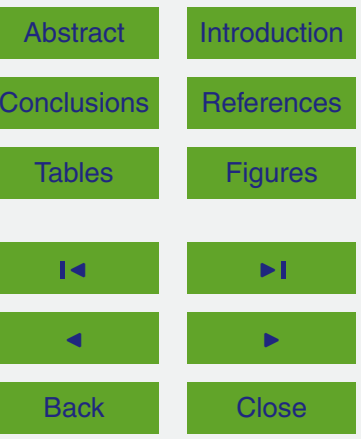

Full Screen / Esc

Printer-friendly Version

Interactive Discussion 

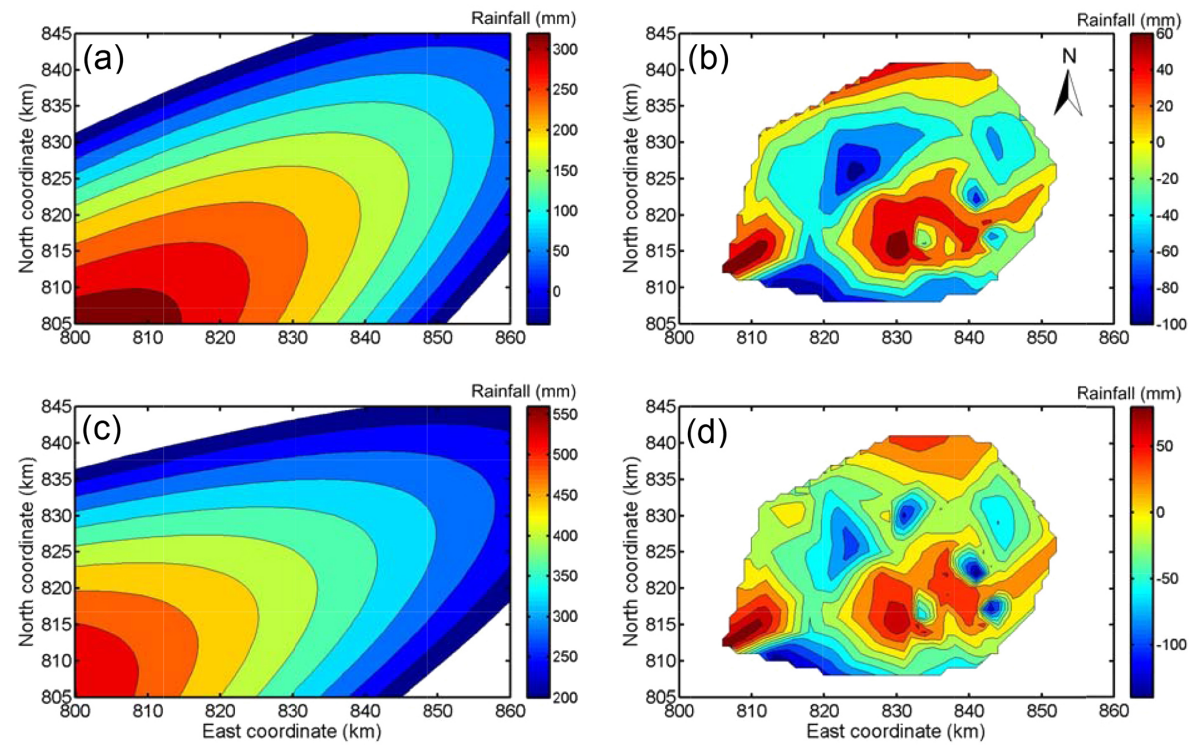

Title Page

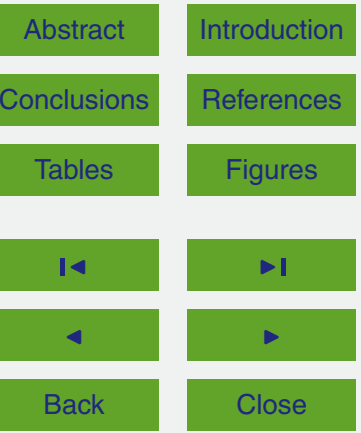

Full Screen / Esc

rolling $4 \mathrm{~h}$ rainfall; (c and d) the maximum rolling $24 \mathrm{~h}$ rainfall.

Printer-friendly Version

Interactive Discussion 


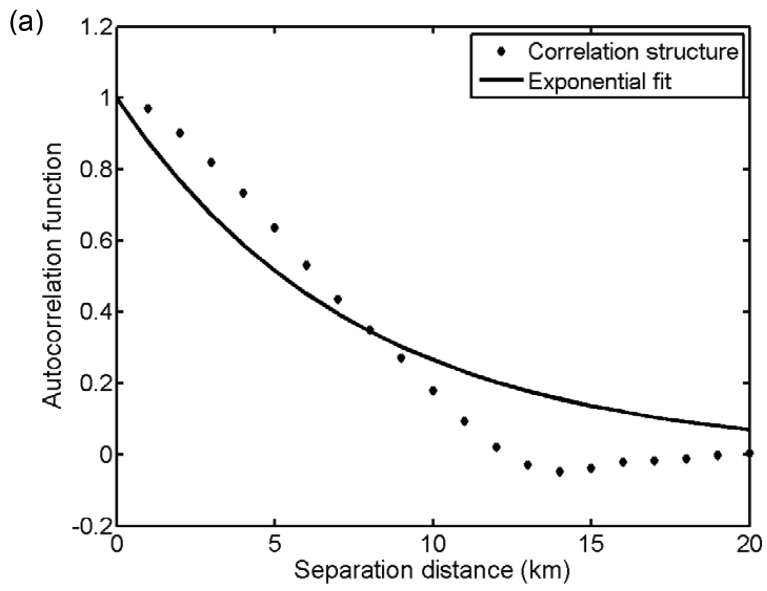

\section{HESSD}

12, 6981-7021, 2015

\section{Spatial}

characteristics of severe storms in

Hong Kong

\section{Gao and L. M. Zhang}

(b)

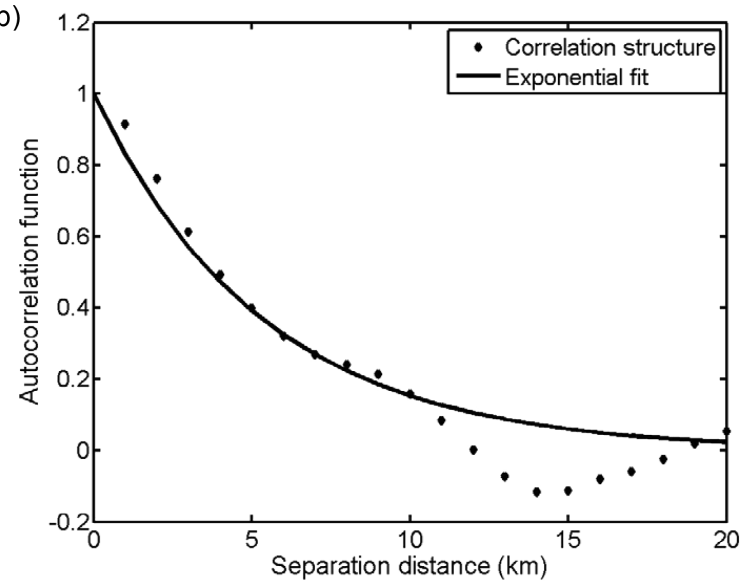

Title Page

Abstract

Introduction

Conclusions

References

Tables

Figures

14

Back

Close

Full Screen / Esc

Printer-friendly Version

Interactive Discussion

Figure 11. Autocorrelation functions for the 5-7 June 2008 storm in the horizontal directions: (a) maximum rolling $4 \mathrm{~h}$ rainfall and (b) maximum rolling $24 \mathrm{~h}$ rainfall. 

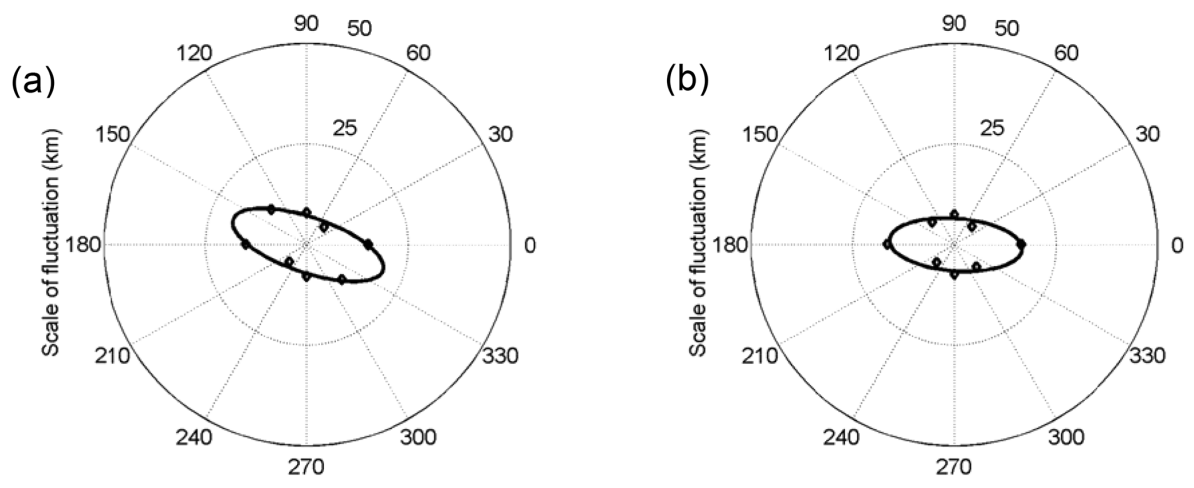

\section{HESSD}

12, 6981-7021, 2015

\section{Spatial}

characteristics of severe storms in

Hong Kong

\section{Gao and L. M. Zhang}
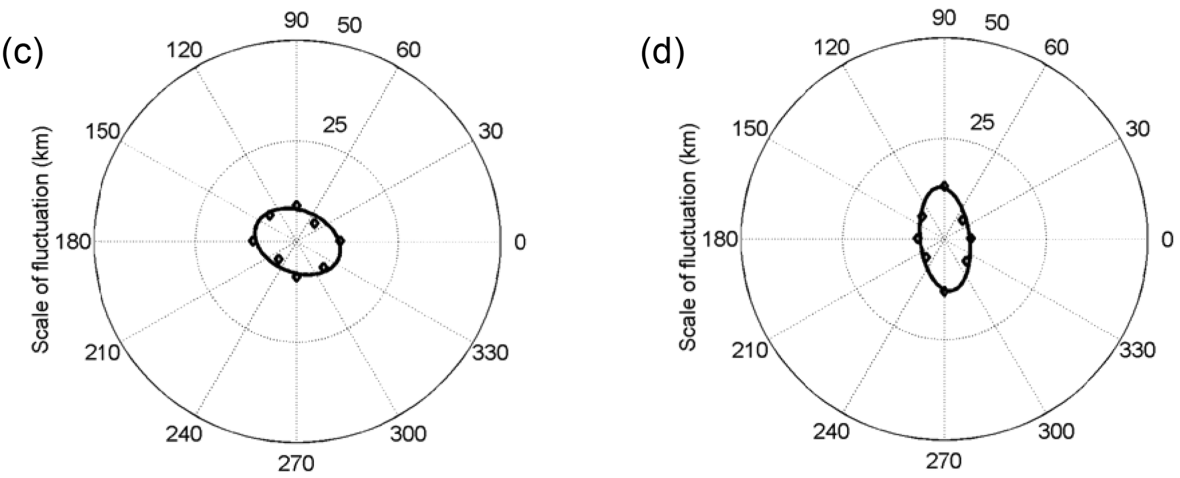

Title Page

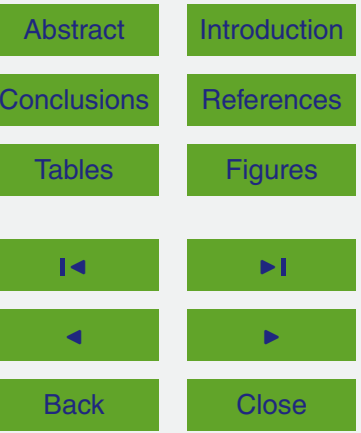

Full Screen / Esc

Figure 12. Scale of fluctuation values and ellipse-fitting curves for the 5-7 June 2008 storm: (a) maximum rolling $4 \mathrm{~h}$ rainfall, (b) maximum rolling $12 \mathrm{~h}$ rainfall; (c) maximum rolling $24 \mathrm{~h}$ rainfall; (d) maximum rolling $36 \mathrm{~h}$ rainfall. 

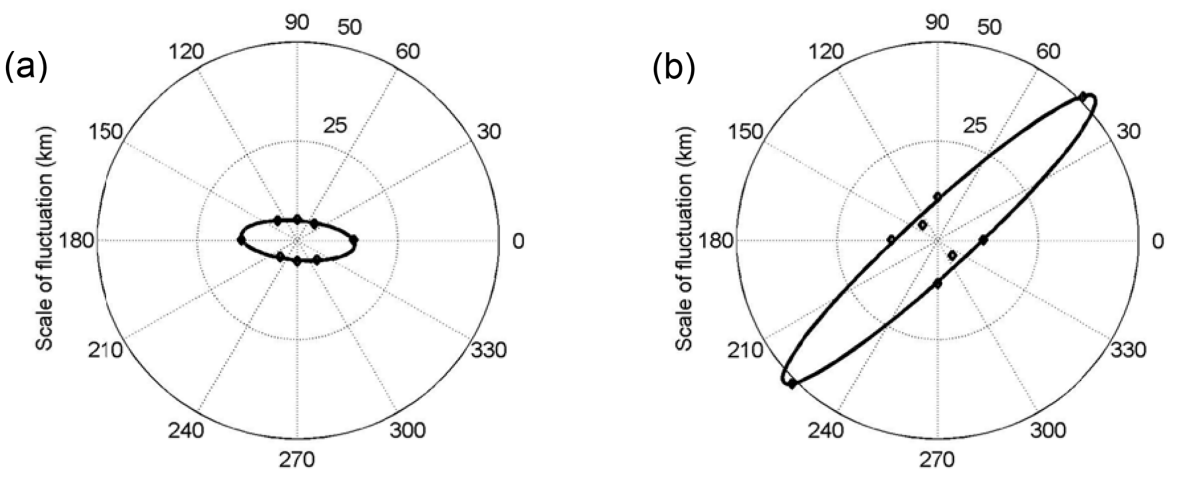

\section{HESSD}

12, 6981-7021, 2015

\section{Spatial}

characteristics of severe storms in

Hong Kong

L. Gao and L. M. Zhang
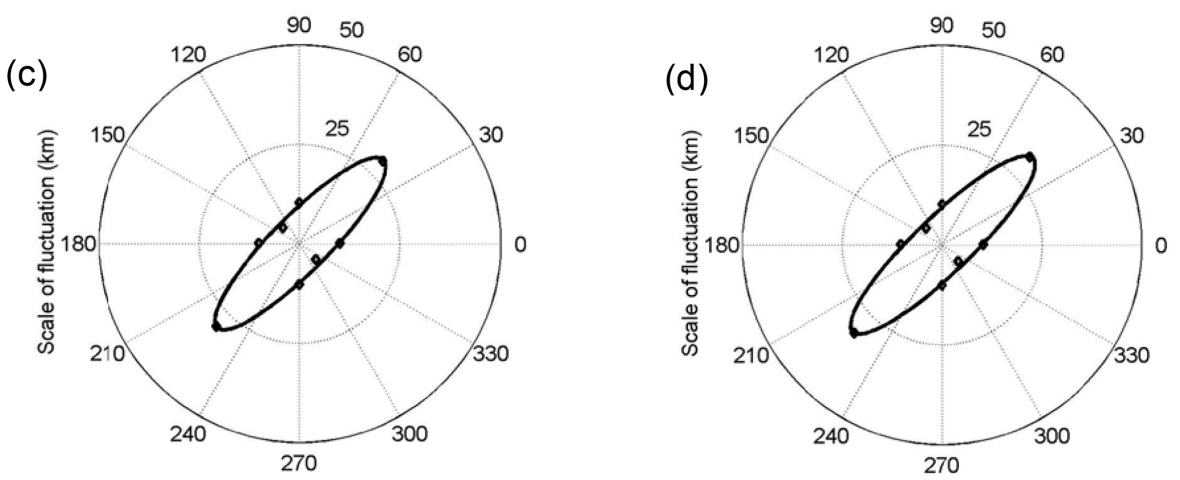

Title Page

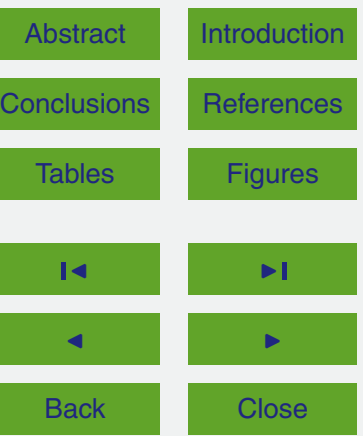

Full Screen / Esc

Figure 13. Scale of fluctuation values and ellipse-fitting curves for the 17-21 August 2005 storm: (a) maximum rolling $4 \mathrm{~h}$ rainfall; (b) maximum rolling $12 \mathrm{~h}$ rainfall; (c) maximum rolling $24 \mathrm{~h}$ rainfall; (b) maximum rolling $36 \mathrm{~h}$ rainfall. 

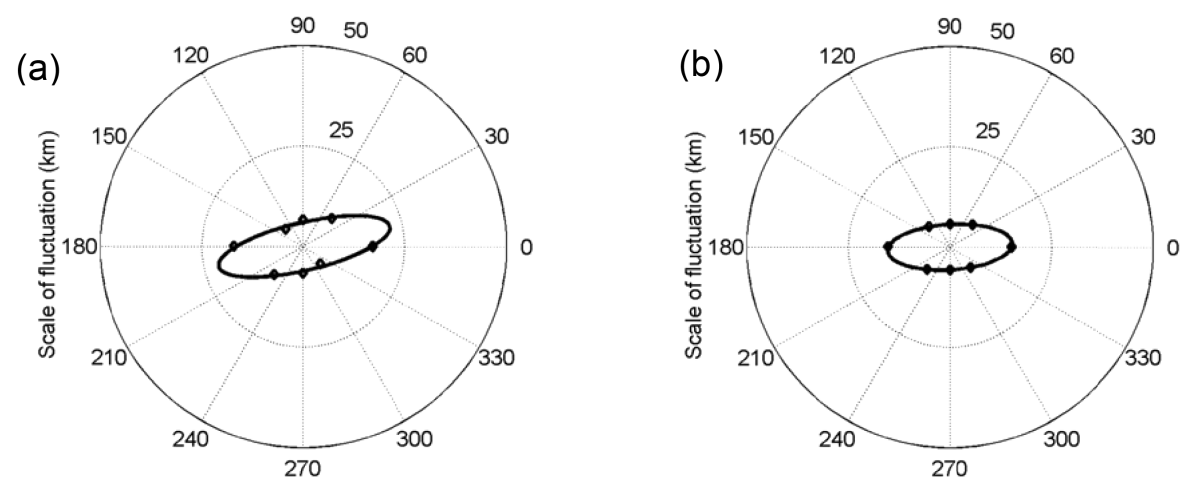

\section{HESSD}

12, 6981-7021, 2015

\section{Spatial}

characteristics of severe storms in

Hong Kong

\section{Gao and L. M. Zhang}
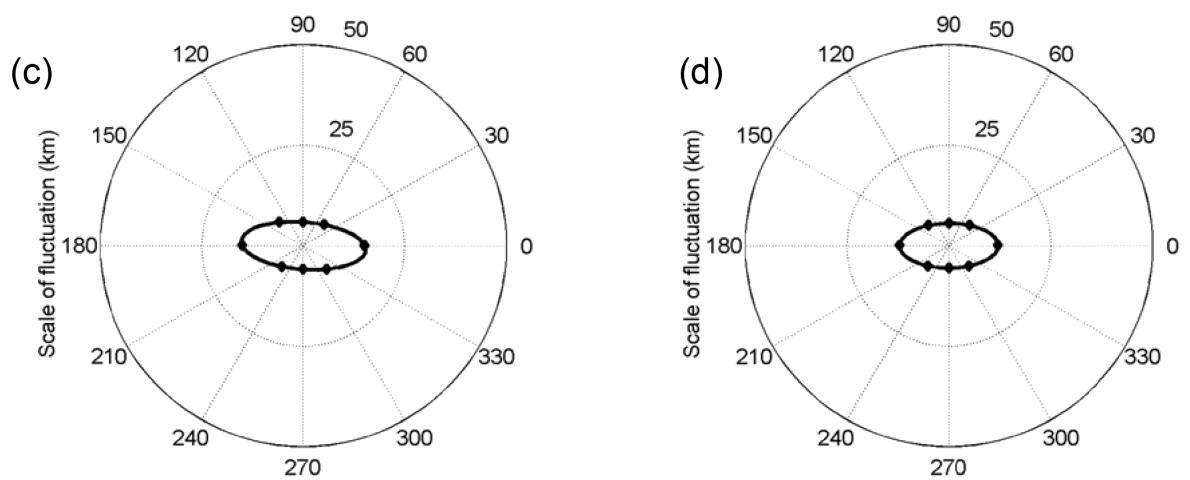

Title Page

Abstract

Introduction

Conclusions

References

Tables

Figures

14

Back

Close

Full Screen / Esc

Printer-friendly Version Figure 14. Scale of fluctuation values and ellipse-fitting curves for the $22-24$ July 1994 storm:
(a) maximum rolling $4 \mathrm{~h}$ rainfall; (b) maximum rolling $12 \mathrm{~h}$ rainfall; (c) maximum rolling $24 \mathrm{~h}$ rainfall; (b) maximum rolling $36 \mathrm{~h}$ rainfall. 


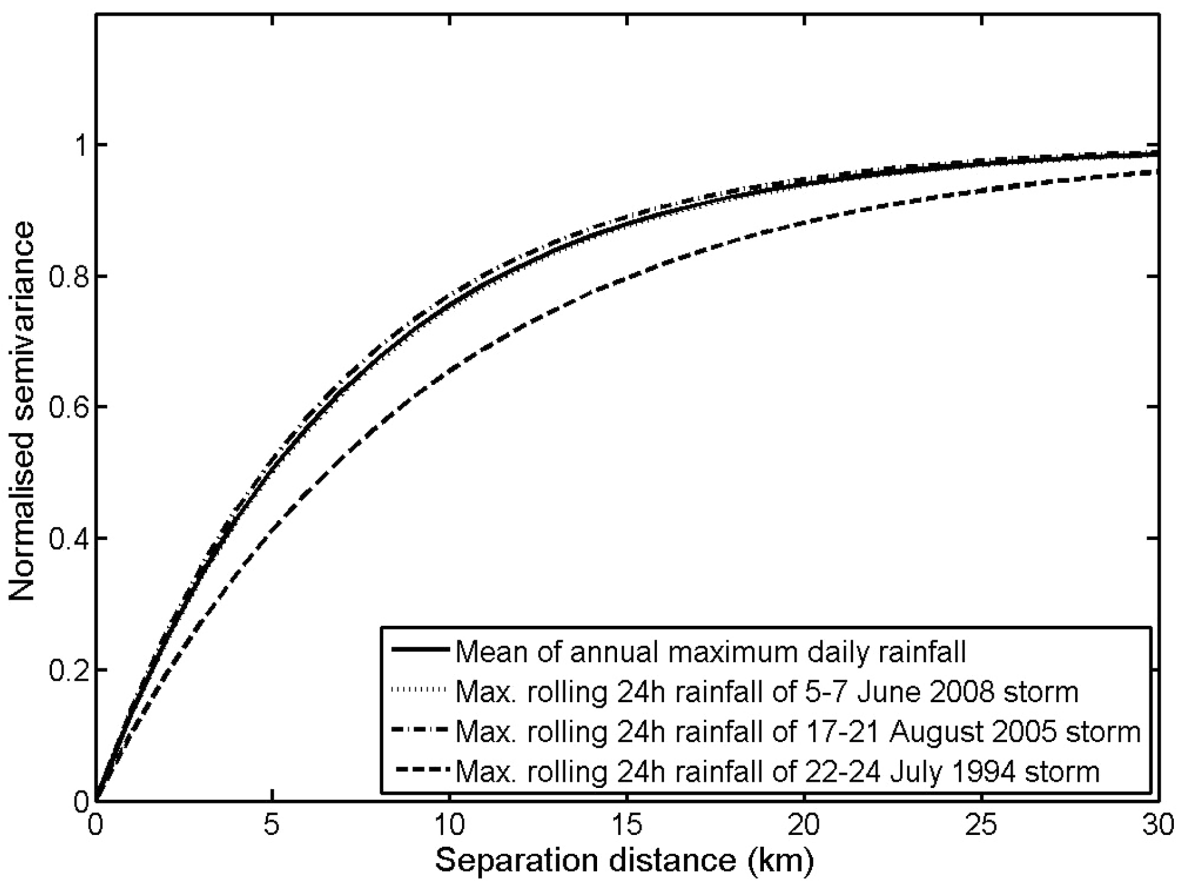

Figure 15. Normalised semivariances of the maximum rolling $24 \mathrm{~h}$ rainfall of the three storms and the mean annual maximum daily rainfall in Hong Kong.

\section{HESSD}

$12,6981-7021,2015$

\section{Spatial}

characteristics of

severe storms in

Hong Kong

L. Gao and L. M. Zhang

Title Page

Abstract

Introduction

Conclusions

References

Tables

Figures

14

Back

Close

Printer-friendly Version

Interactive Discussion 